\title{
Effects of Neutron Irradiation on Non-Fissionable Alloys
}

\author{
B. G. Datagk ${ }^{+}$
}

Brookheven Notfond Laboretory, Epton, New York

This paper was submitted for publication in the open literature at least 6 months prior to the issuance date of this Microcard. Since the U.S.A.E.C. has no evidence that it has been published, the paper is being distributed in Microcard

\section{LEGAL NOTICE}

This report was prepared as an account of Government sponsored work. Nelther the United nor any person acting on behalf of the Commission

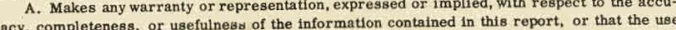
of any information, apparatus, method, or process disclosed in this report may not infringe privately owned rights; or B. Assumes any liabllitles with respect to the use of, or for damages result
uBe of any information, apparatus, methor, $n$ proreas disclosed in this report,

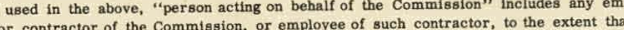
such employee or contractor of the Commission, or employee of such contractor prepares, disseminates, or provides access to, any information pursuant
with the Commission, or his employment with such contractor.

form as a preprint.

"aper to be presented at the Internationa Atomis Energy Ageney Symo postuns in Vendee, Italy, May 7, 1962.

* Supported in part by the U. S. Aconde Znex ay comiston.

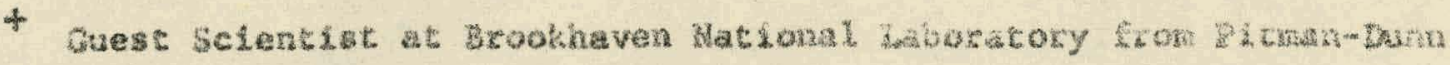

Laboratories, Rrankford Arsenah, Fhlladelphis, Fensylvania. 


\section{DISCLAIMER}

This report was prepared as an account of work sponsored by an agency of the United States Government. Neither the United States Government nor any agency Thereof, nor any of their employees, makes any warranty, express or implied, or assumes any legal liability or responsibility for the accuracy, completeness, or usefulness of any information, apparatus, product, or process disclosed, or represents that its use would not infringe privately owned rights. Reference herein to any specific commercial product, process, or service by trade name, trademark, manufacturer, or otherwise does not necessarily constitute or imply its endorsement, recommendation, or favoring by the United States Government or any agency thereof. The views and opinions of authors expressed herein do not necessarily state or reflect those of the United States Government or any agency thereof. 


\section{DISCLAIMER}

Portions of this document may be illegible in electronic image products. Images are produced from the best available original document. 


\section{ABSTRACT}

Neutron irradiation can cause three major effects in non-fissionable alloys: 1) the excess vacancies produced by irradiation can accelerate diffusion; 2) point defects and regions of strain can serve as additional nucleation sites for phase changes; 3) the displacement of atulns may cause a breakup of ordered or precipitated regions. By the proper choice of a 110y systems, the first two effects have been isolated and examined in detail.

Essentially pure enhanced diffusion can be achieved in short-range ordering alloys such as the $\alpha$-phase of $\mathrm{Cu}-\mathrm{Z}_{\mathrm{n}}$ and $\mathrm{Cu}-\mathrm{Al}$. A quantitative theory was developed which shows that the temperature and flux dependence of enhanced diffusion varies with the relative amounts of excess vacancies and of their trapping sites in the solid. The predictions of the theory for high trapping site concentration have been verified in $a_{n}-z_{n}$ by neutron irradiation, and those for the low trapping site concentration by positive ion bombardment. Experiments on $\mathrm{Cu}-\mathrm{A} 1$ indicate that the low trapping site case can be achieved in this alloy with neutrons. These experiments also show that by controlled irradiation an ailoy can be put into a low temperature state which cannot be achieved by thermal means alone..

The change in the number of nucleation sites has been studied in the iron-carbon system. Since the carbon diffuses interstitially the diffusion rate cannot be accelerated, and no precinitated regions exist in freshly quenched specimens. Therefore, a11 changes in the rate of disappearance of 
carbon from solution must be related to trapping, viz., nucleation phenomena. After a few hours irradiation at ambient temperature, internal friction measurements of the carbon peak showed that it disappears ten times faster than the thermal rate. The implication that ten times the nuclei are present is confirmed by electron microscope studies. After several days irradiation at low temperature, however, the rate of disappearance of carbon from solution is one thousand times the thermal rate and is governed precisely by the activation energy for diffusion of carbon in iron. Detailed studies of this phenomenon witin electrical resistivity measurements show several decay steps which are related to the interaction of the carbon atoms with point ciefects. 


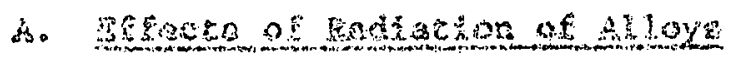

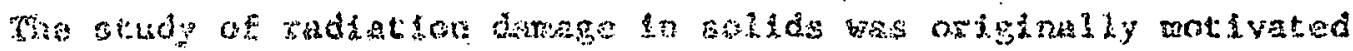

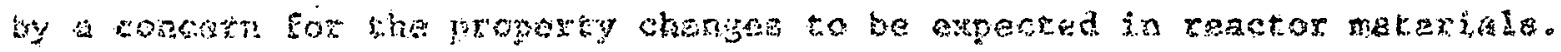

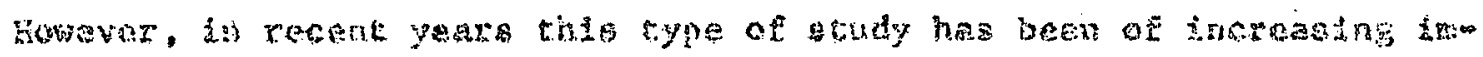

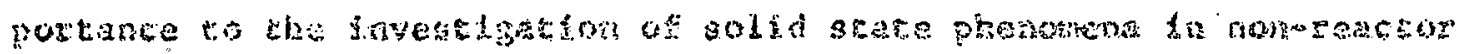

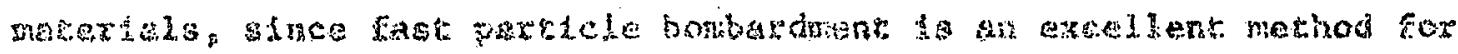

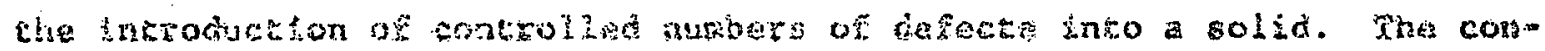

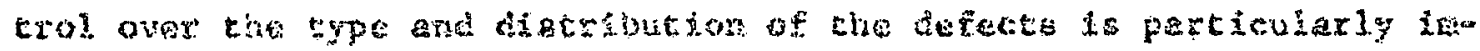

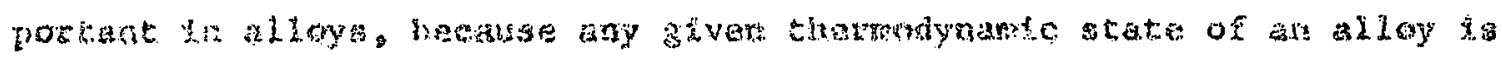

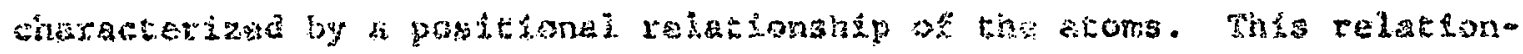

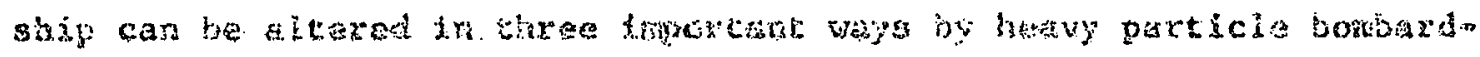
mente.

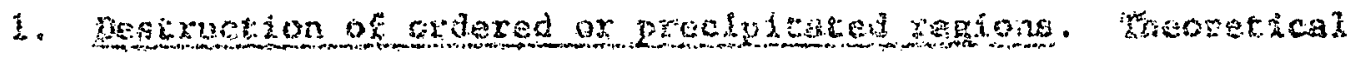

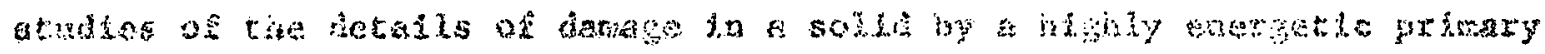

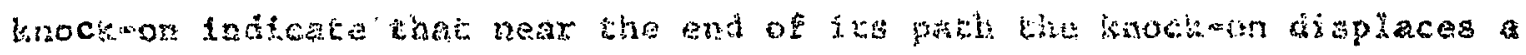

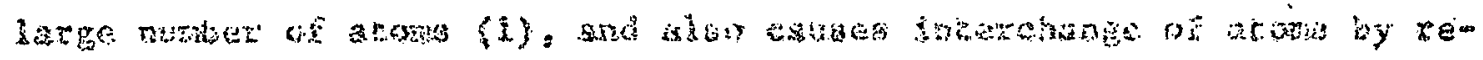

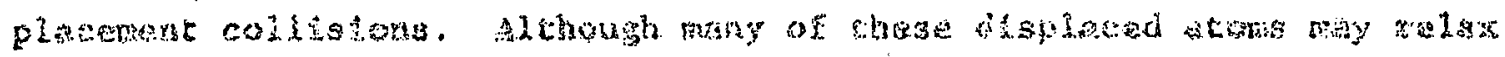

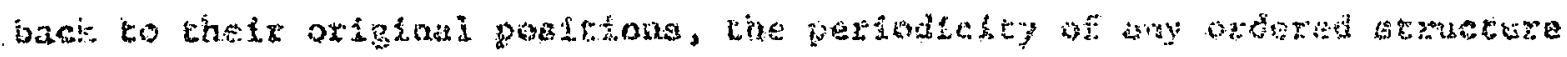

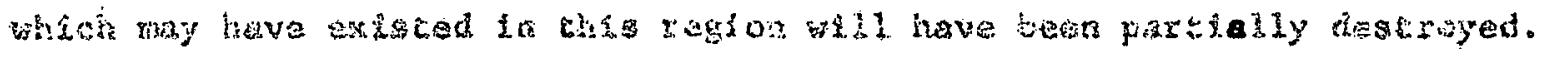

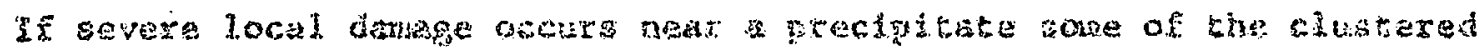

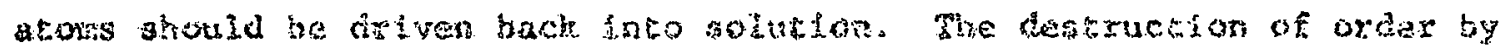

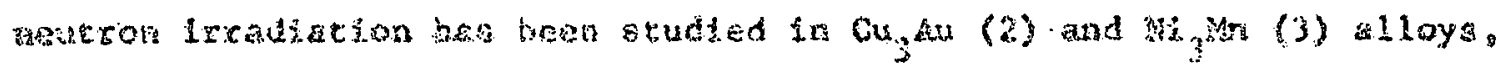

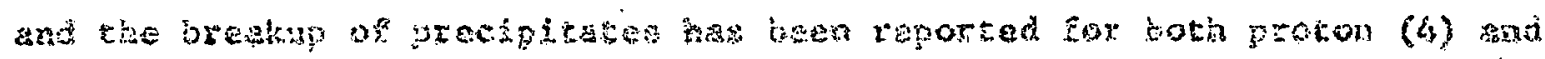
neltron (5) borbardiant: of: No-Cu.

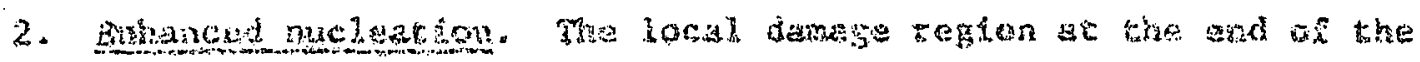

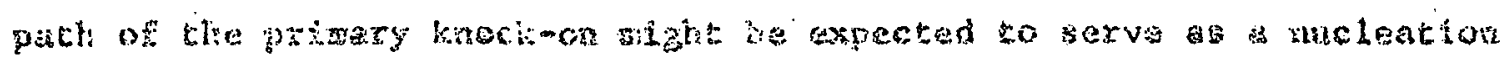




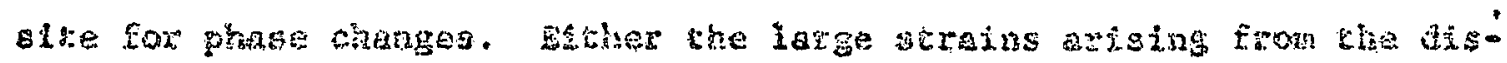

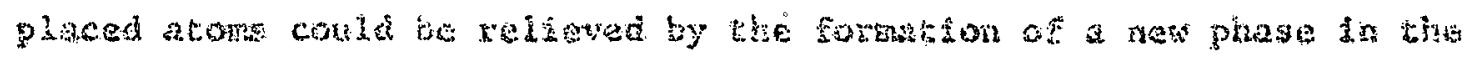

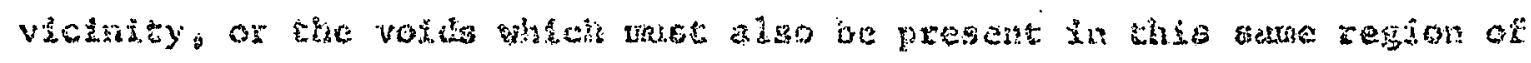

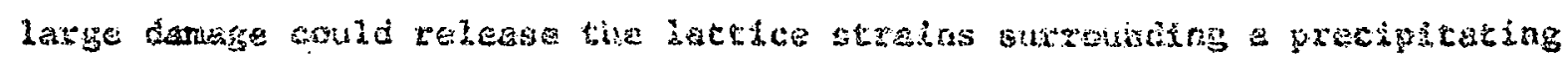

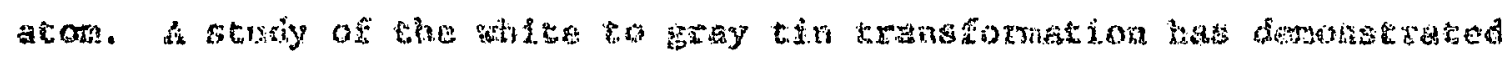

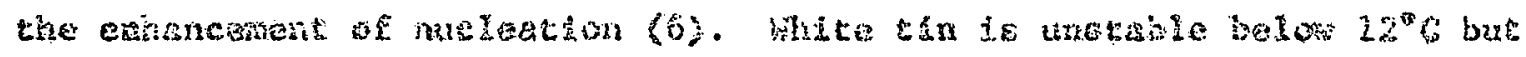

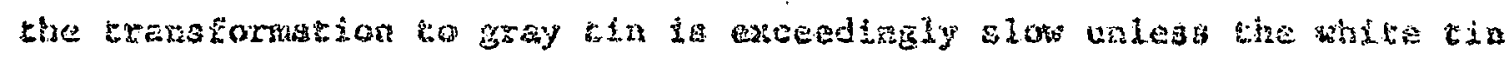

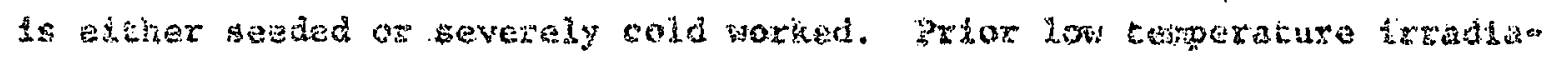

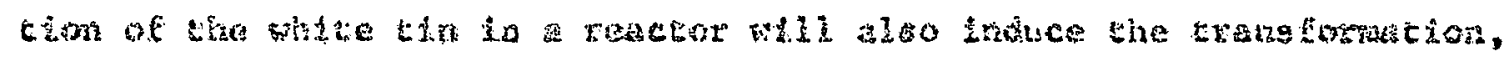

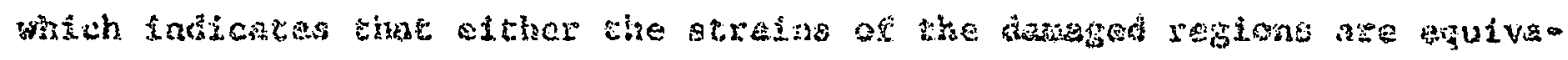

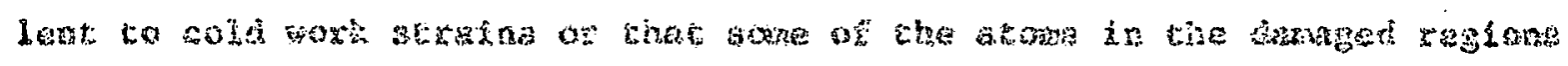

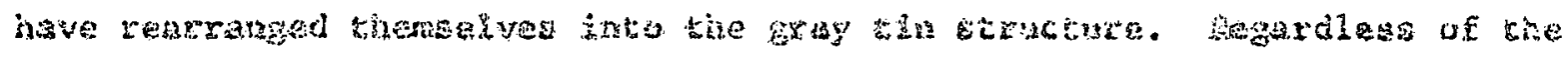

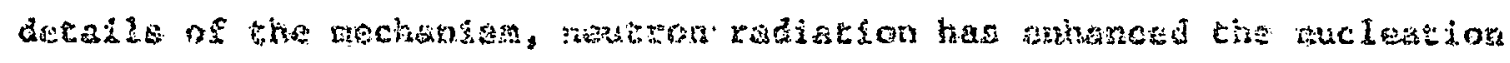
of the ghase thatgo.

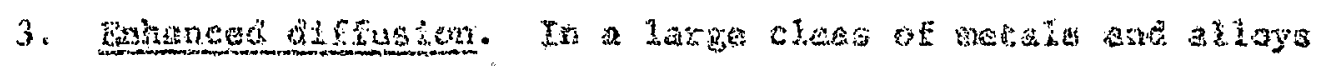

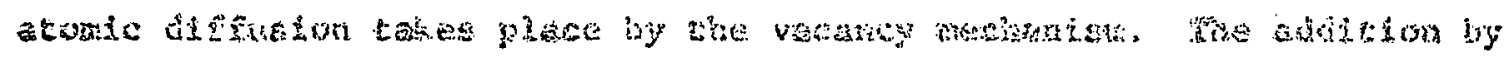

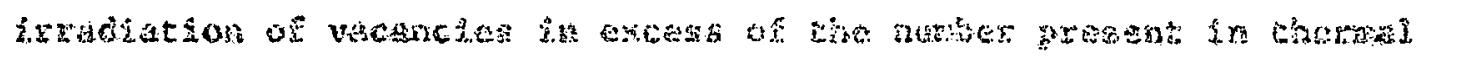

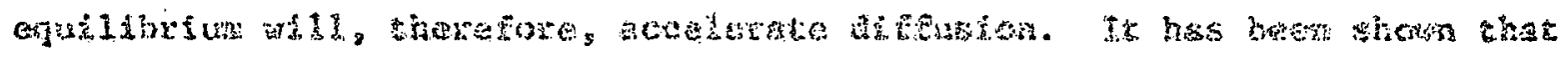

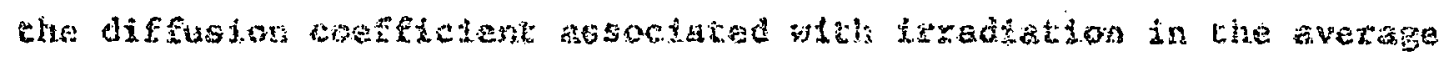

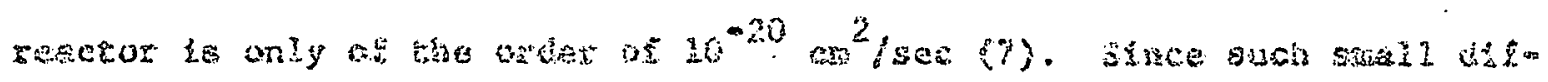

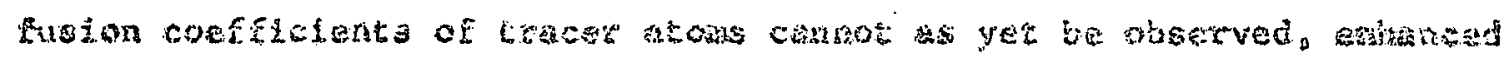

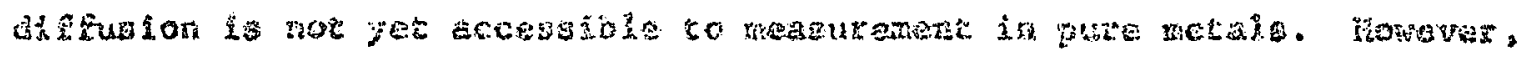

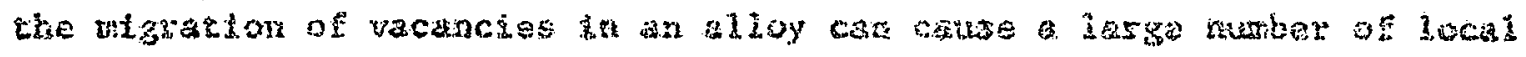

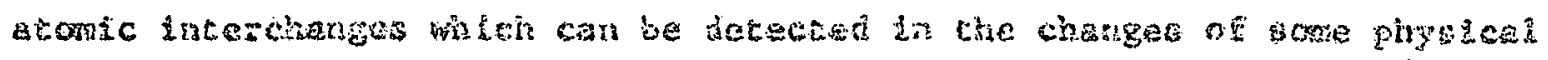

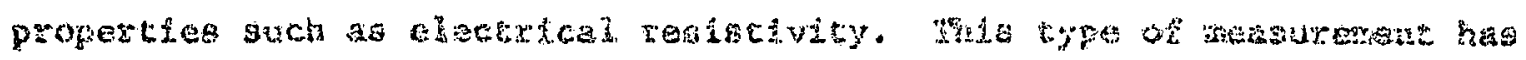

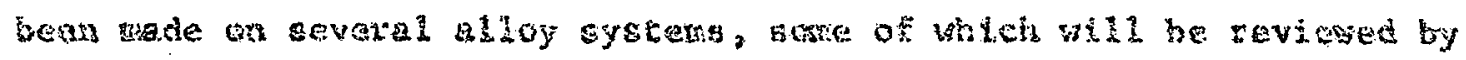


M. Wechader in this sympositur.

If the bombarding particle efther has a lov energy or i. Ifght In mas (alectrons or r-rays), the severe local damse and replacenent collistons diacksaed above are not expected. Ondy the simie displacement of stome occurs and, therefore, only angle vacacy-interatitial pasts are created. As far is known no deacruction of order oz creation of nucleation centers occure wth electron or gama Irradiation and, thezetore, only the enhanced diffusion effect 1s expected. Since during the dexadiction of many alloys at leat zwo of the above effecto are occurring

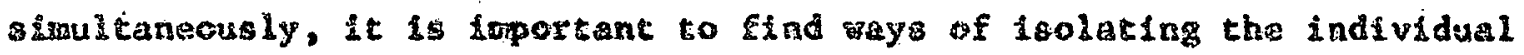
effocti for a quantitative study of each. Fo af these effacto, enbanced

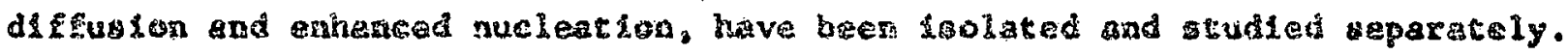

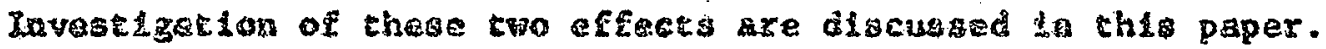

\section{B. Eghanced Dffusion}

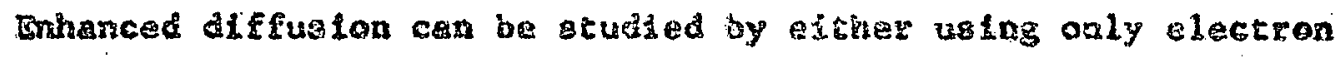
or r-ray cadiation or by choosing an alloy sysem fn which enisaced di

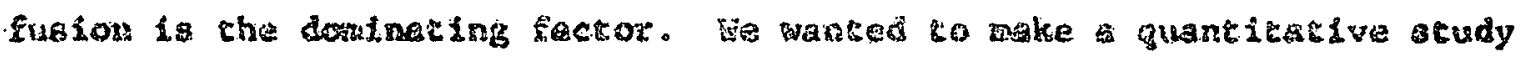

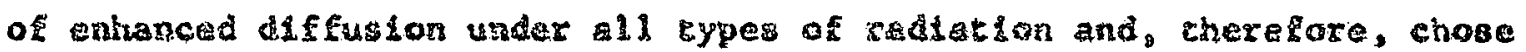
an alley, cobras, in shen shis to the jor effect. This alloy has proved to be a Eoktunste cholee for these atudies in many respects (8). It doe not bocome unosmageably radloactive afcex nevtron irratation; the slfghe preference of the fu-zn bod cewas short-range or werfing without the developwent of long-range order; equllibrdum short-range order lis actieved in reagonable leaghs of thas in the tomerature range of $170-300^{\circ} \mathrm{C}$; omall. chenges In ahort 3 ange order cause large changeg in the 


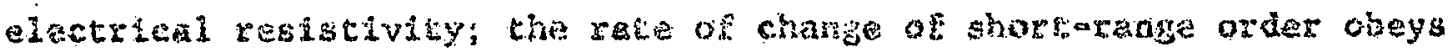

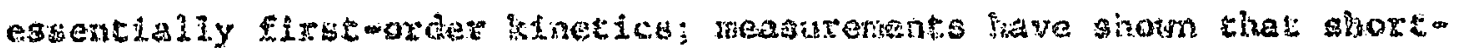
range order \&s noc nombeably deatroyad by a few hours of heavy particle

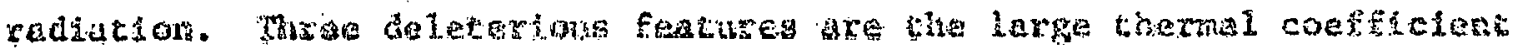
of electracal resistivity, the very similar wegay seartering of copter

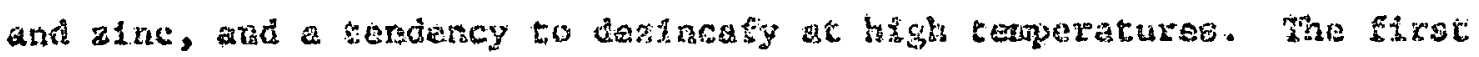

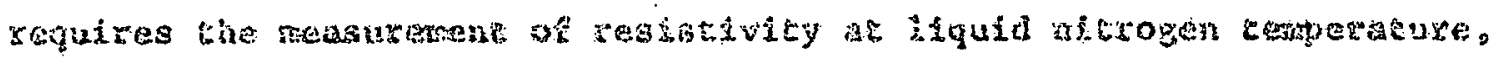

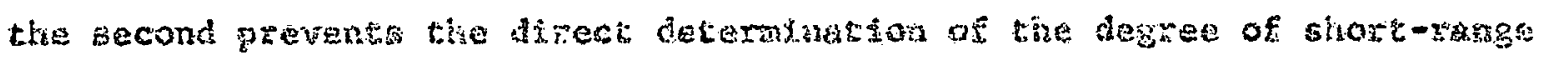

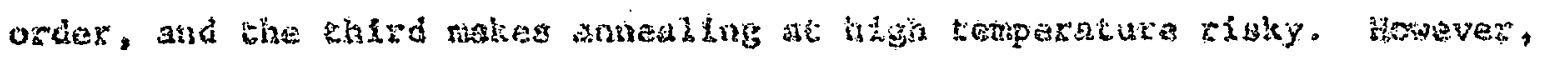

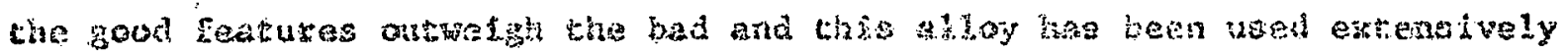

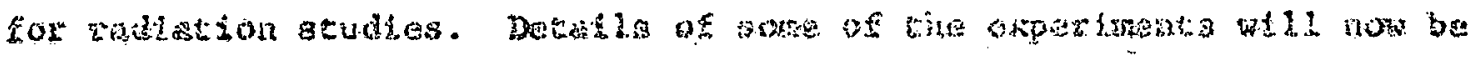
given.

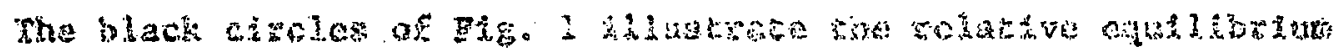

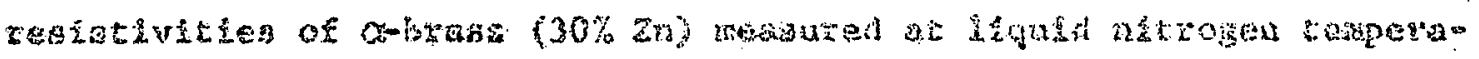

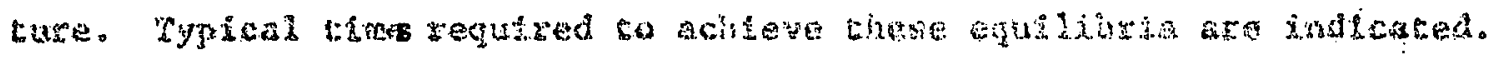

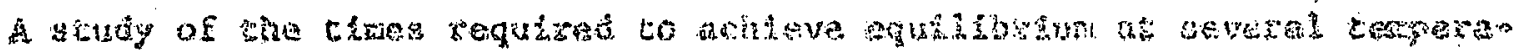

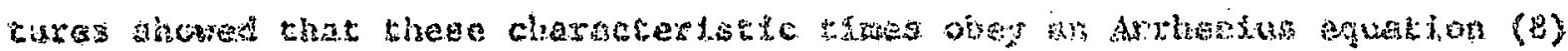

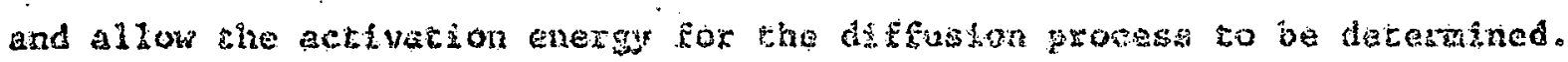

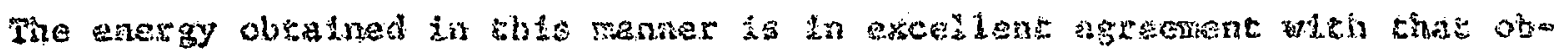

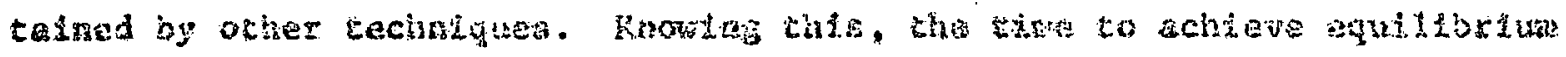

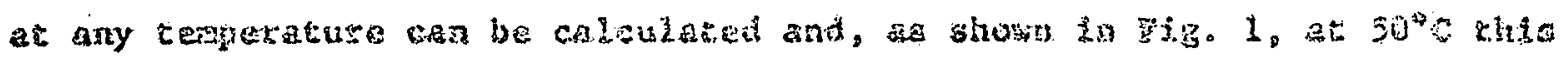

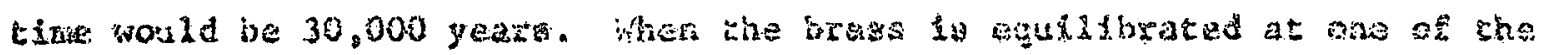

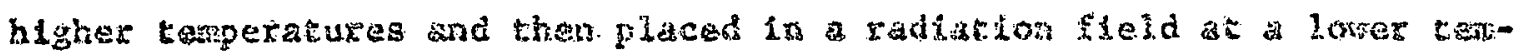

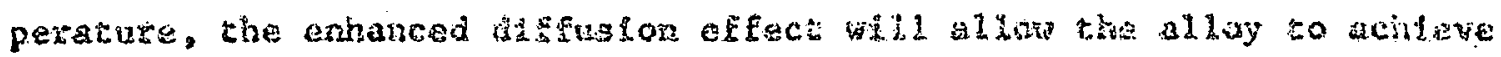

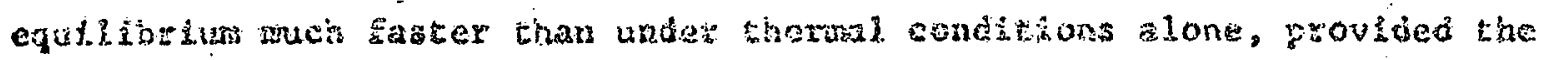




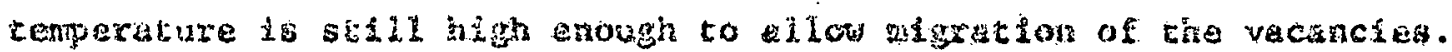

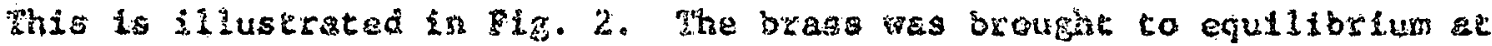
$210^{\circ} \mathrm{C}$ and then $2 x^{2}$ adinged at $50^{\circ} \mathrm{C}$ in the reactor and the resiotivity de*

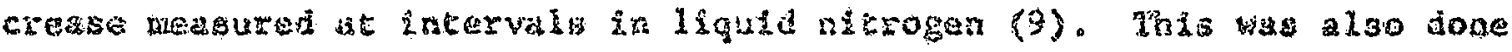
on otser samples in a 2 wey alectron beam and at $20^{\circ} \mathrm{C}$ in a $850,000 \mathrm{R} / \mathrm{sur}$ 60

co source. The tinal value achieved by ofx hours of eldecron radia-

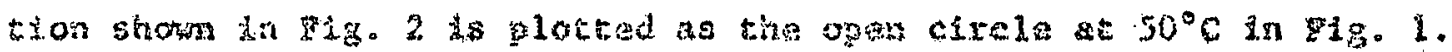

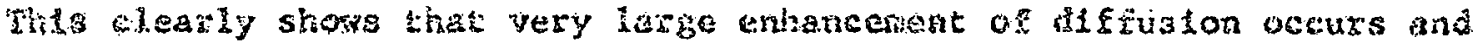

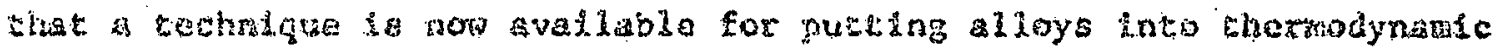

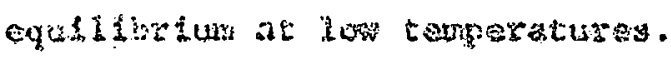

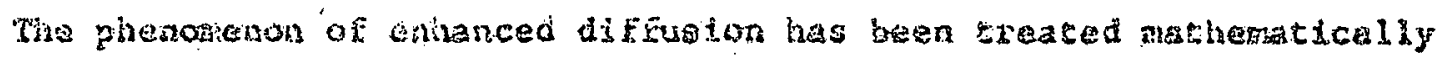

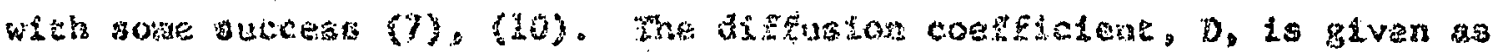

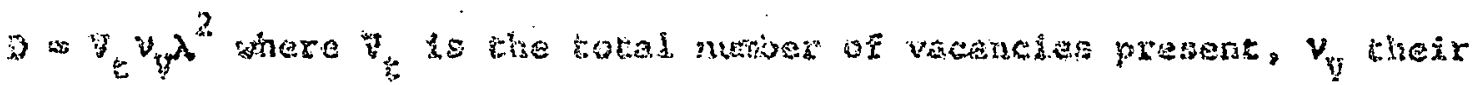

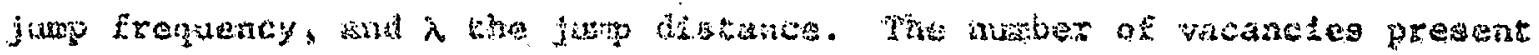

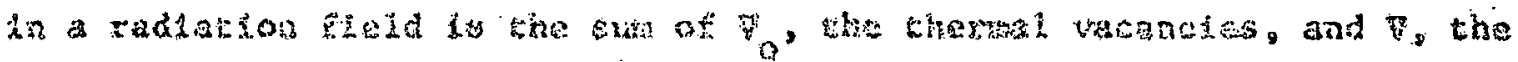

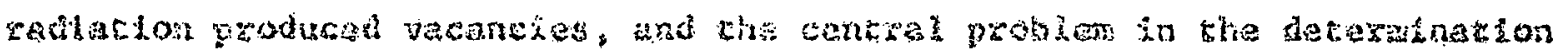

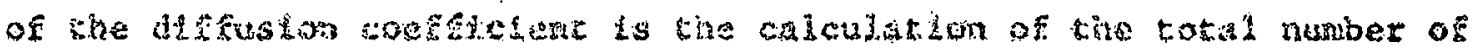

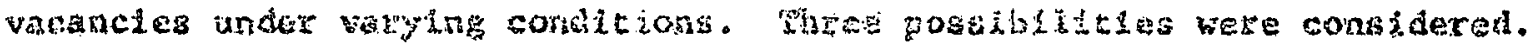

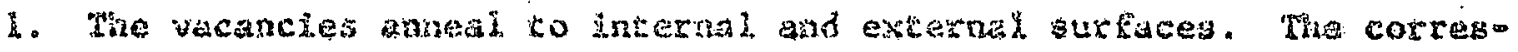
ponding differonctal egaction î

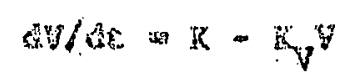

where $\mathrm{R}$ it the rate of vesney producelon and is proportorul to the radiation Elux, aud $\mathrm{k}$, is the constant of vacancy estape and is propor- 


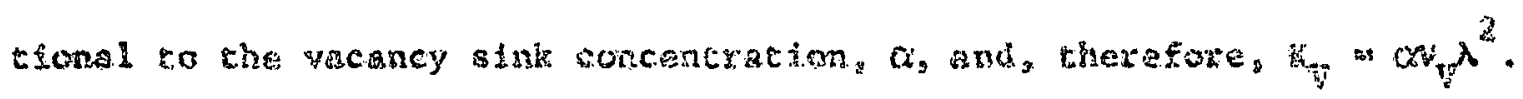

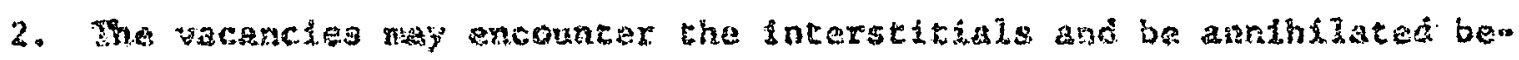

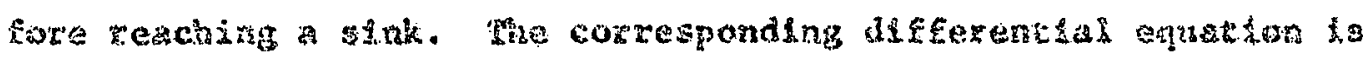

$$
d V / d t=2-V t
$$

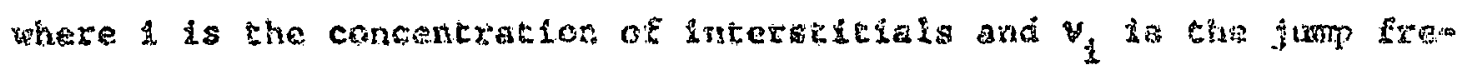

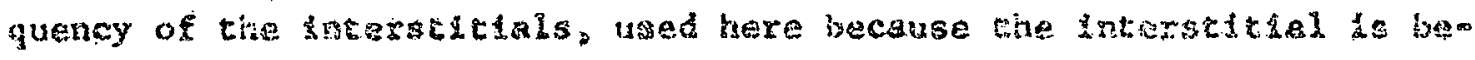

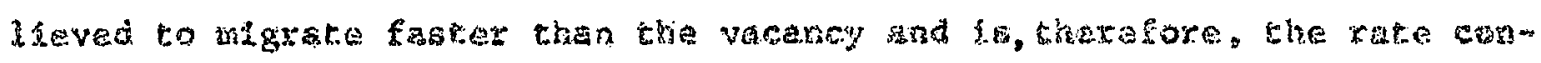
krolling factor. 3. The vacancles nay to remeved thy bots of thase prow cerses at the ratie ting, shen

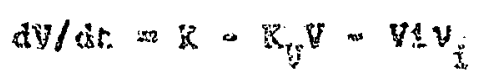

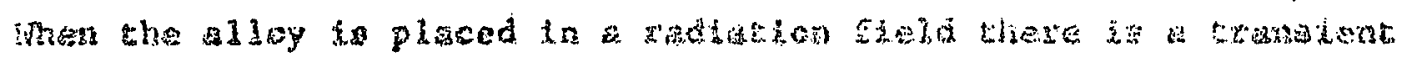

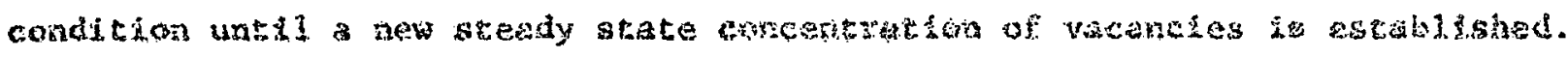

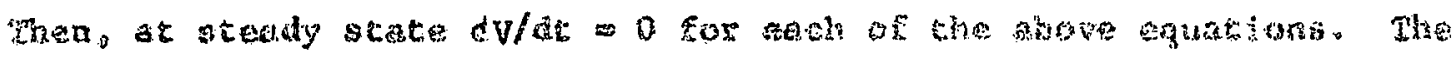

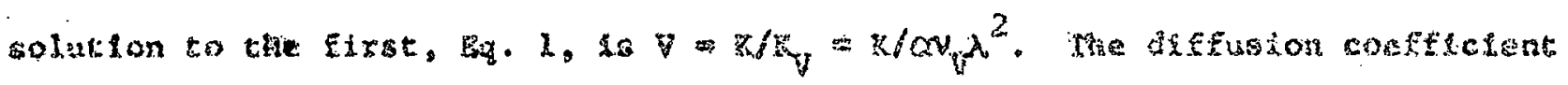

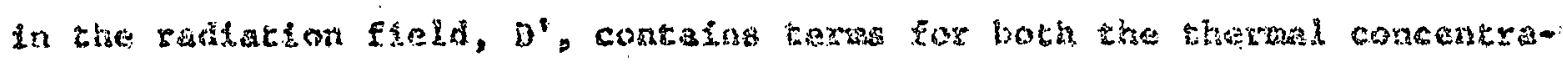

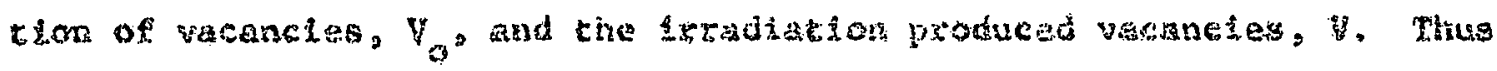

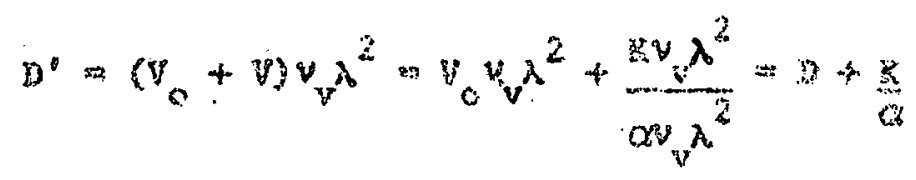

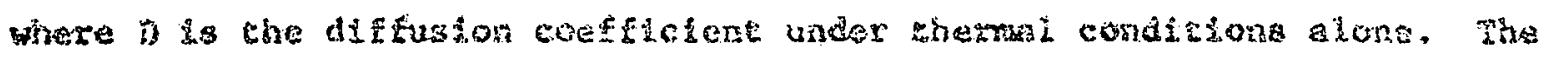

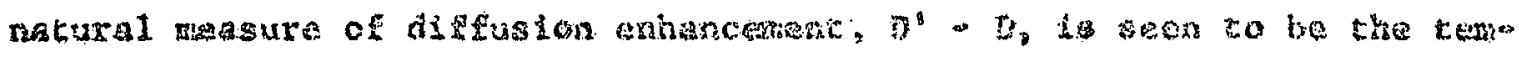


perature independent constant $\mathrm{K} / \alpha$. The solution to this, and the other two conditions appear in Table $x$. 
sable

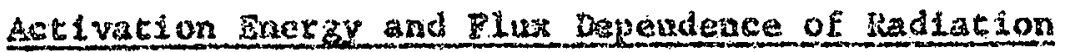

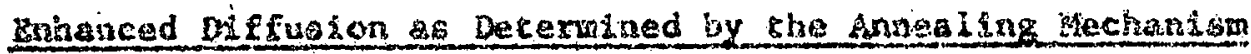

( Arnealing

Astrvatlon Sorgy fot

Hux Deperdence of Enleaced Diffuglor

Enhanzed Diffuslon

Linesr

$\cdot 0$

Recombination

Recombingtion plus izmeax
$E_{m}^{v}-(1 / 2) E_{m}^{q}$

$(1 / 2) \mathrm{E}_{\mathrm{E} 2}^{v}$
Linear

Square Root

Square EDoc 


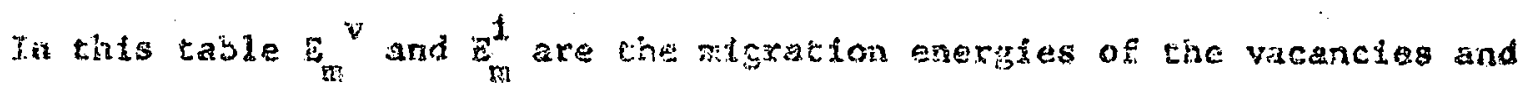

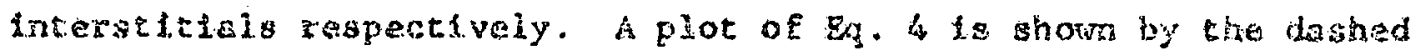
curve of Flg. 3; the soldd line in the ryermal diffuston, The ondiate

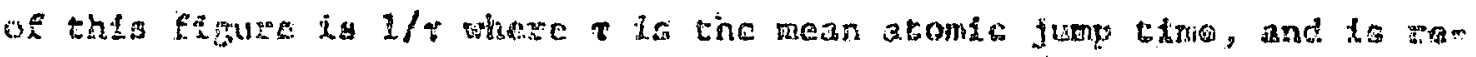
lated to the diffuston coeffichent in f.c.r. metalo by

$$
D \lambda^{2} / 12(2 / \tau)
$$




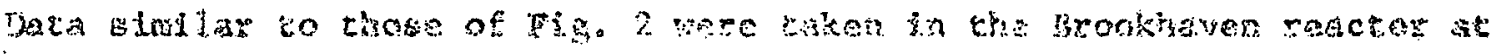

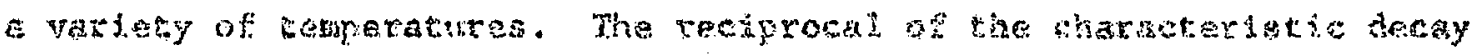

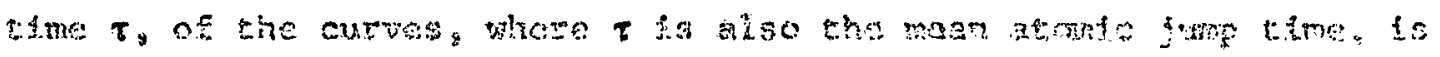

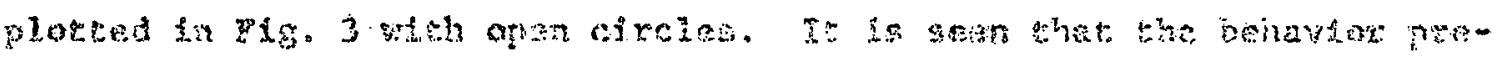

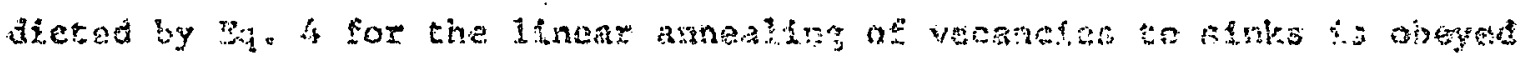
End, by rae of

The validty of this gimple theory has bewn furher dmpnstratad

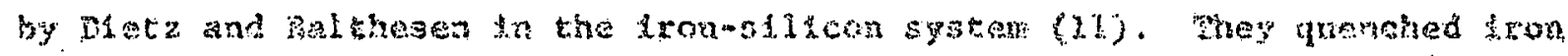

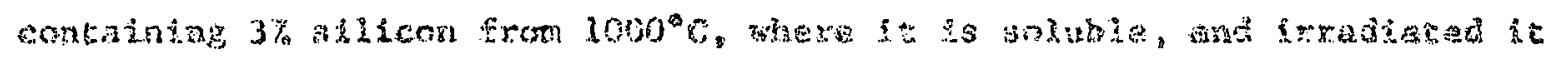

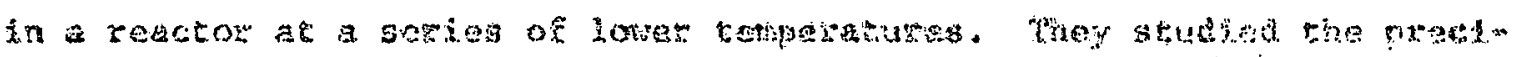

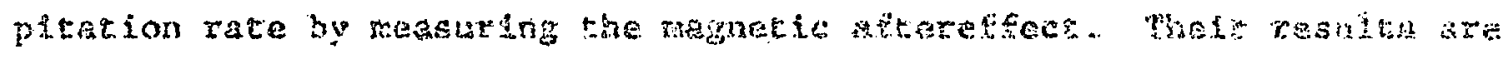

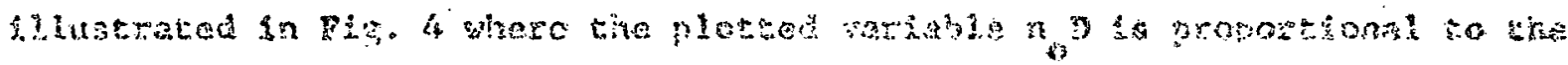

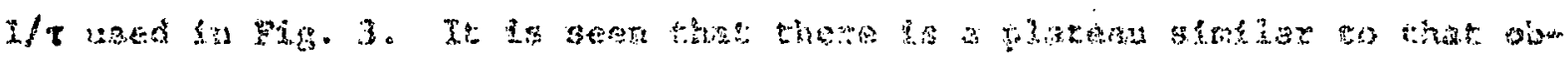

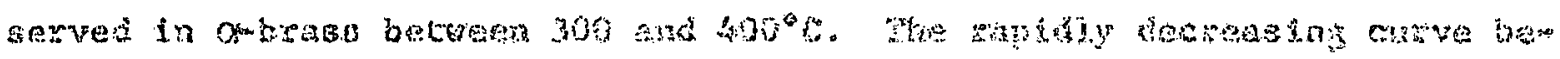

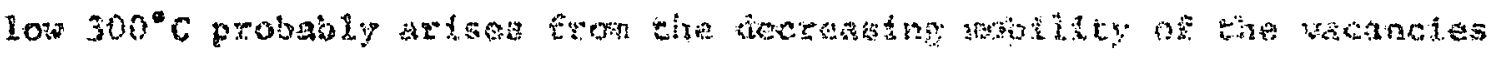

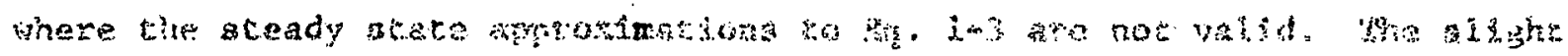

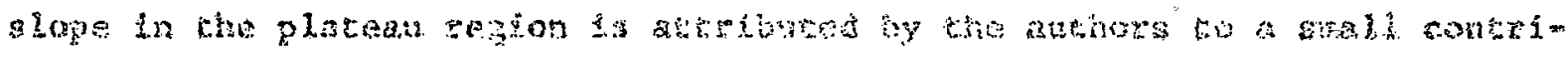

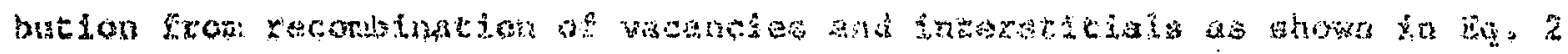

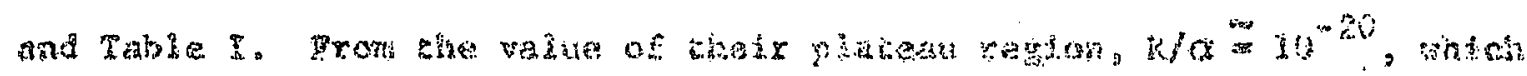

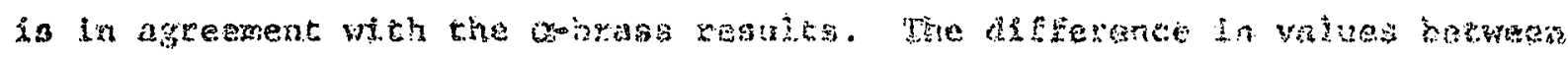

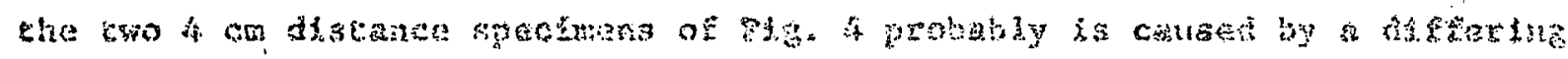

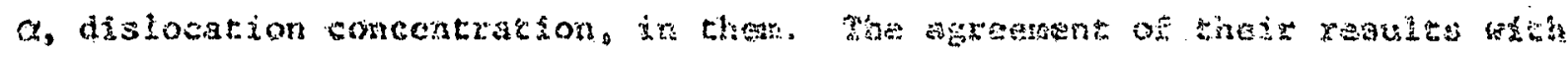

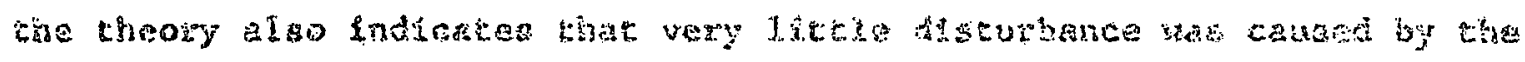
breakup of prechptrate olusters. 
trudt and Hins (12) have succeeded in obchining the care governed

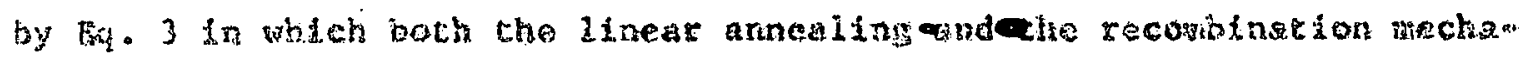

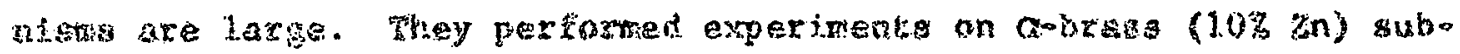

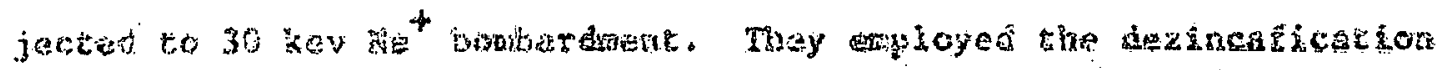

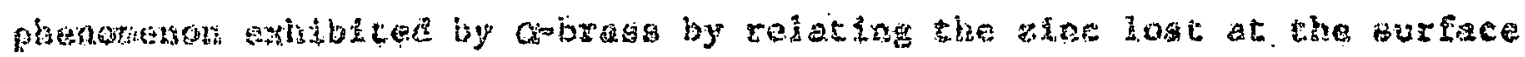

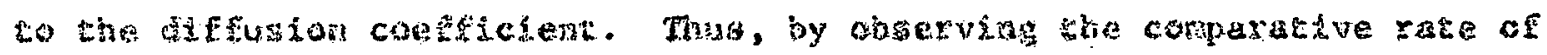

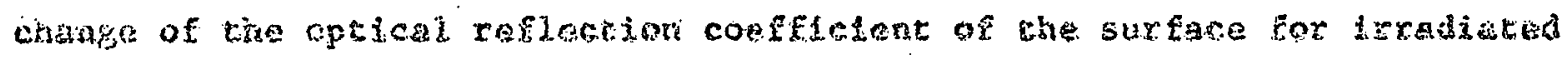

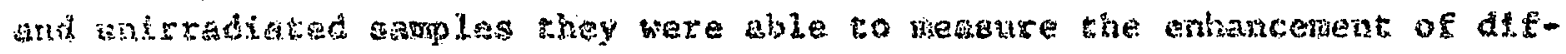

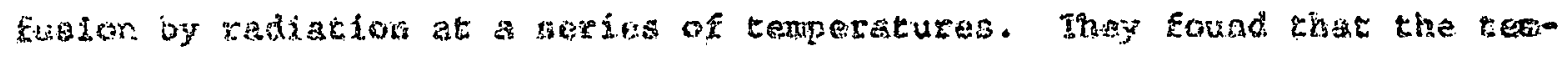

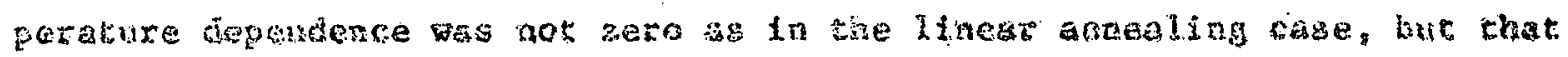

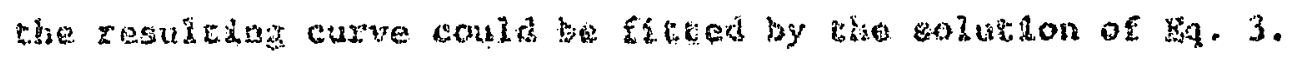

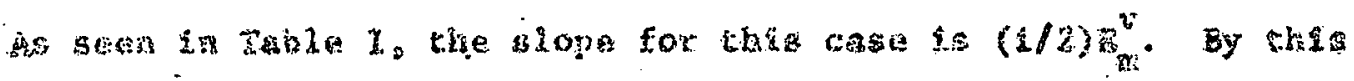

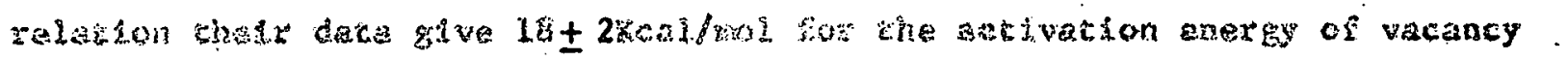

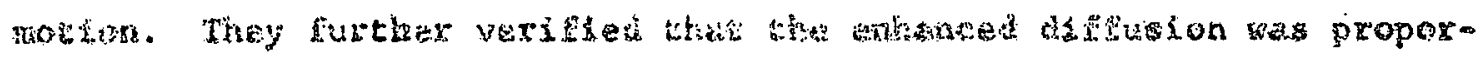

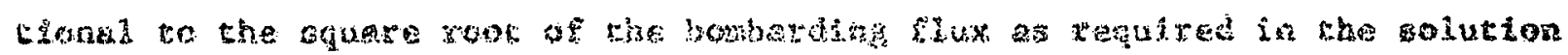
of $3 \cdot 3$.

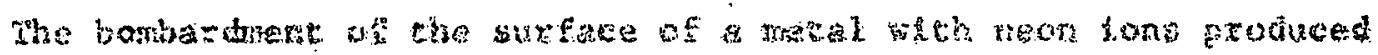

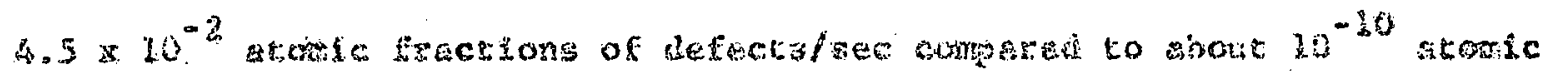

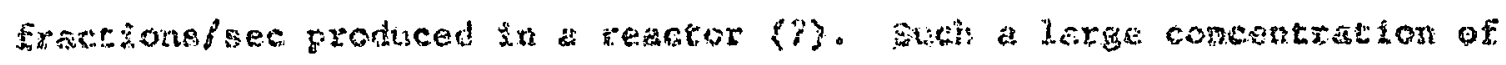

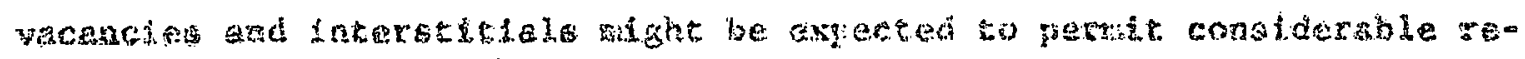

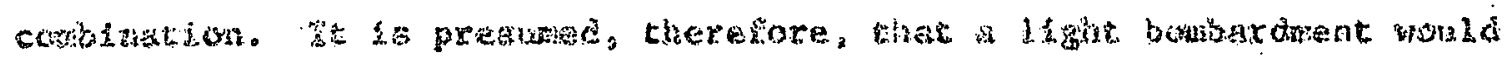

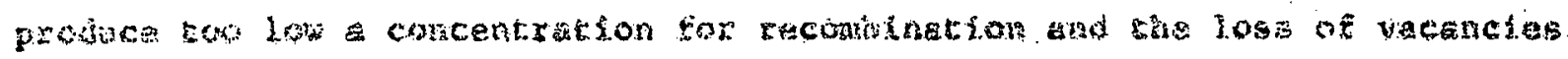

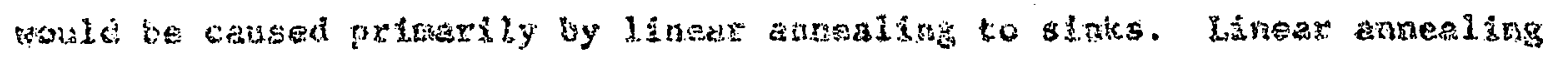

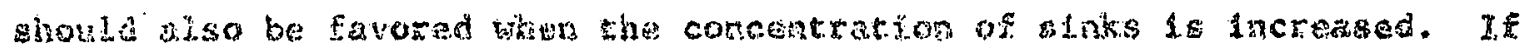

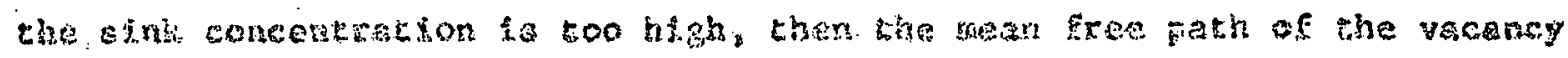




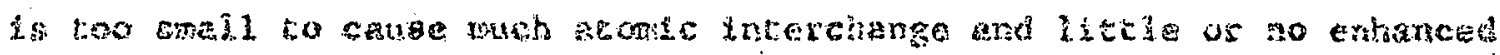

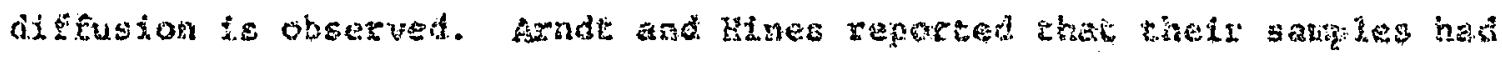

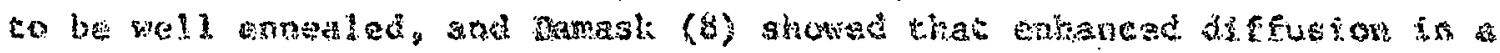

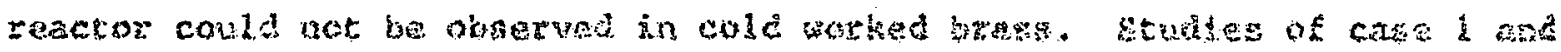

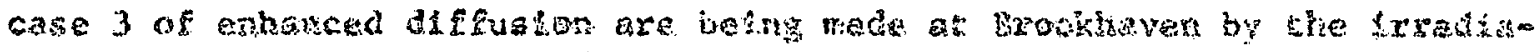

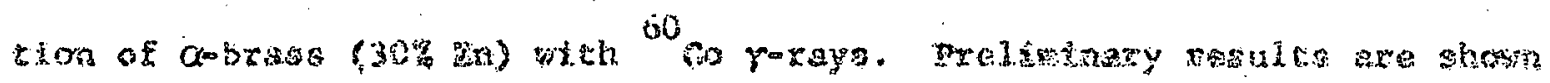

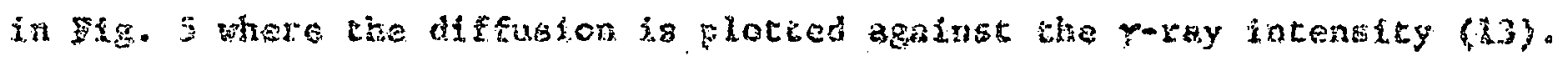

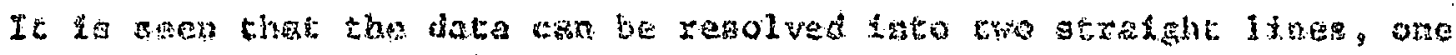

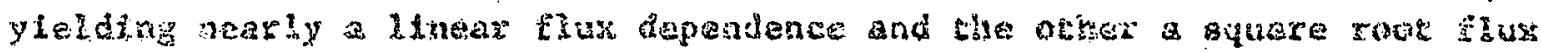
dependence, whon a trangtion region betwen. This $r$-ray wors is not como

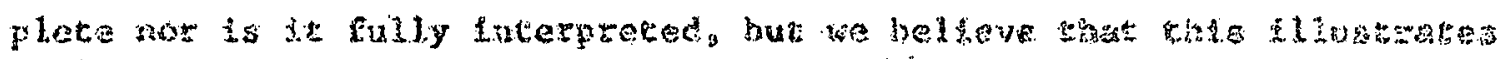

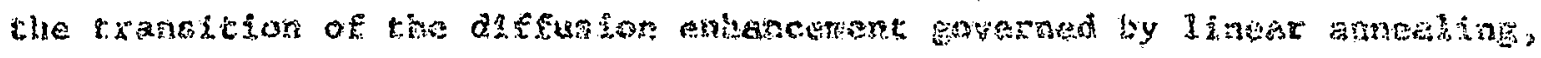

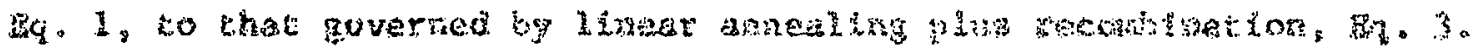

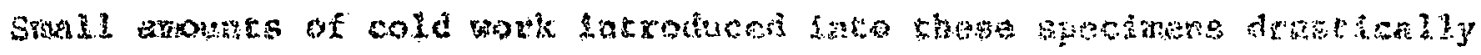

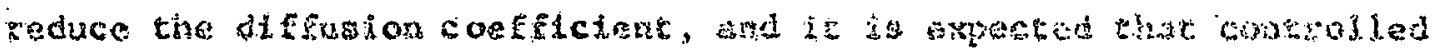

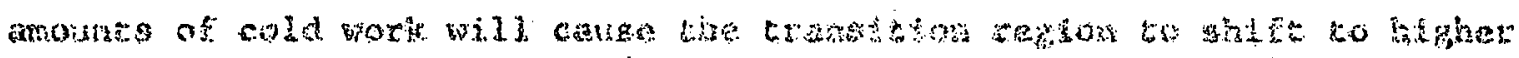

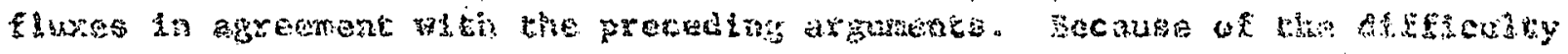

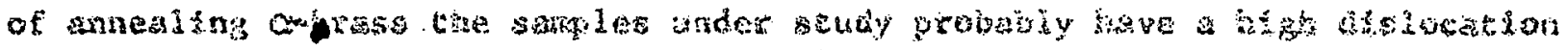

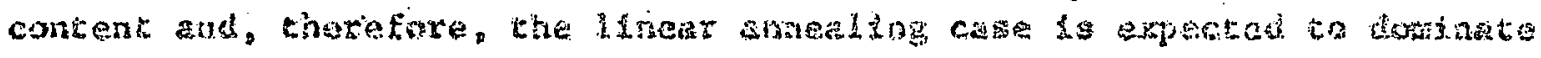

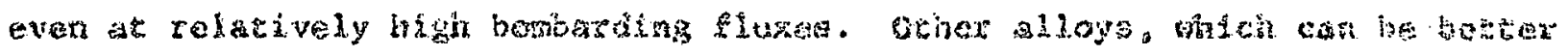

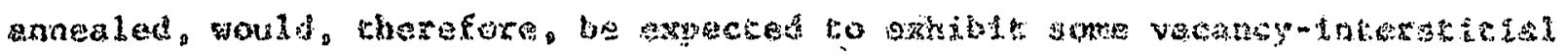

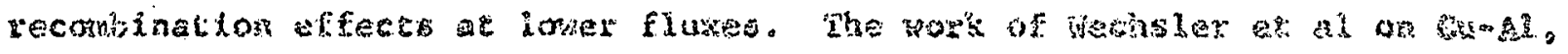

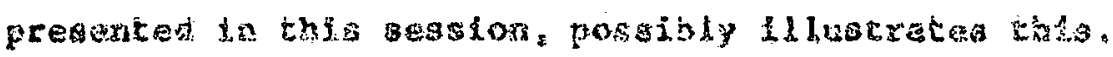

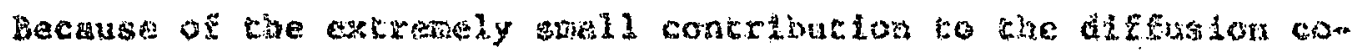

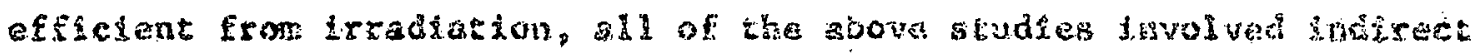




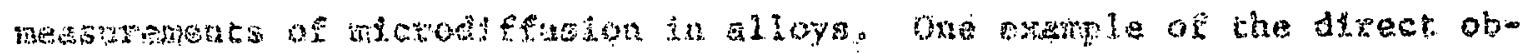

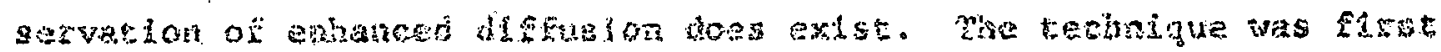

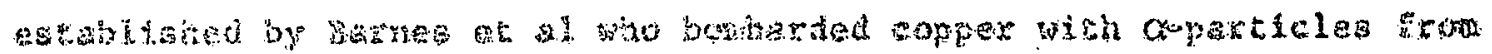

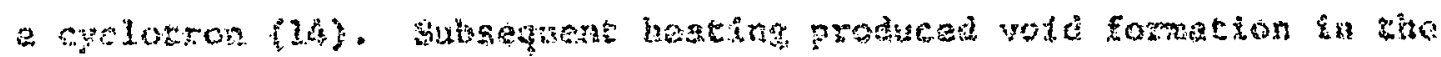

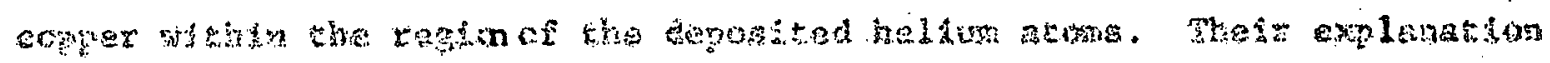

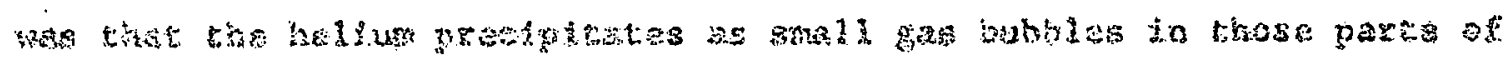

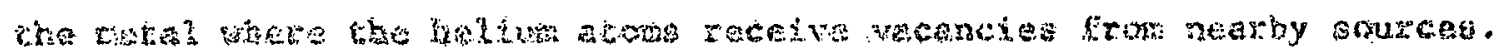

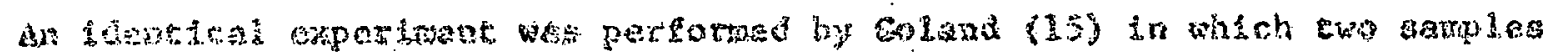

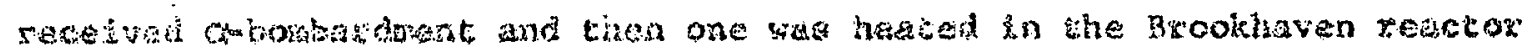

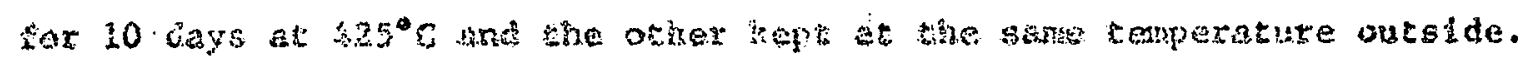

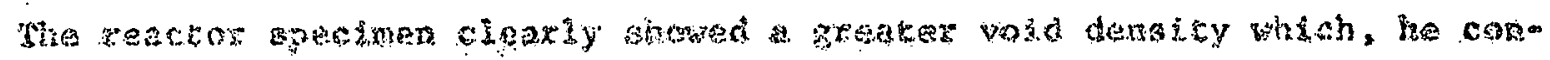

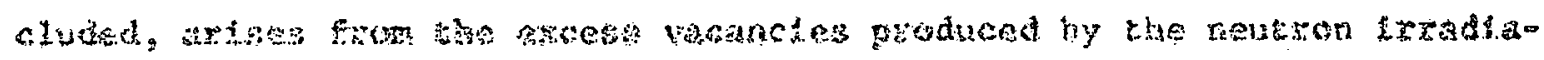
tosing

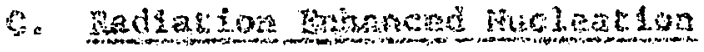

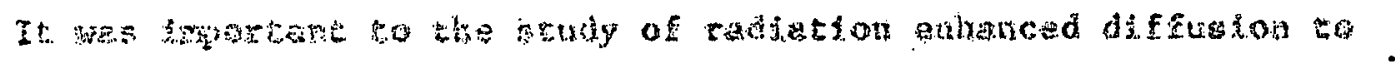

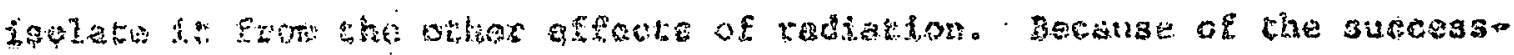

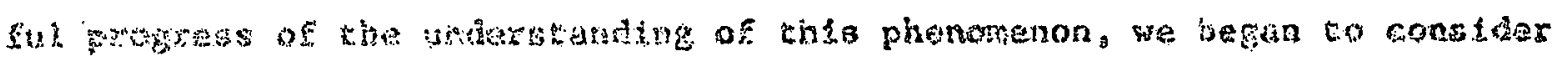

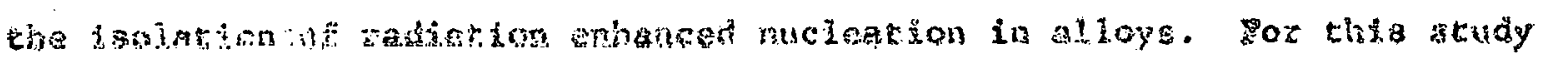

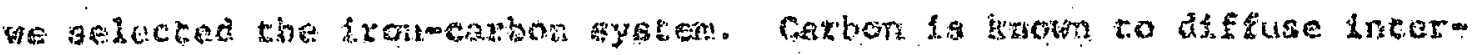

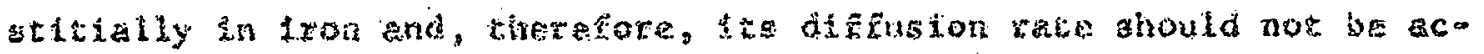

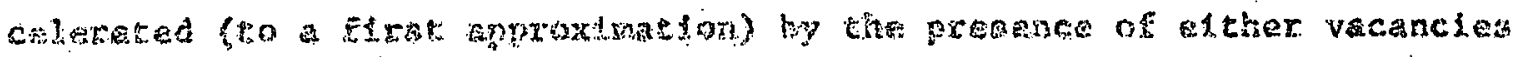

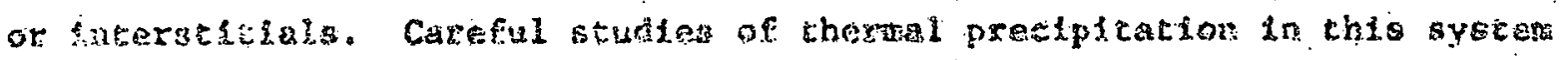

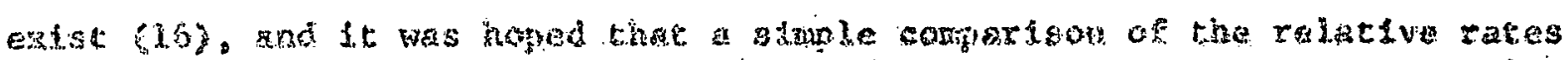

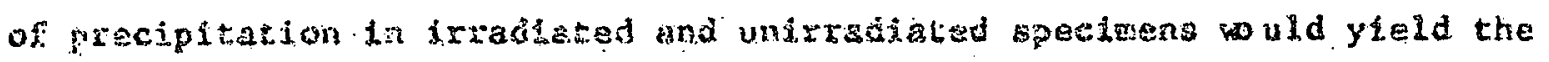

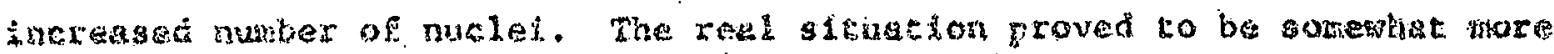
anisy. 
The rate of disappearince of carbon which had been quenched into solution in 1row ( 0.01 wr. \% carbon) was measured by lts contribution to the internal friction (Snoek) peak. (17). The internal friction peak

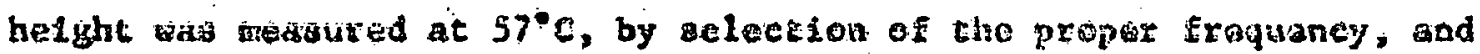
1ts decay observed as a function of time. The sumples were then placed In the Brooksaven reactor at $57^{\circ} \mathrm{O}$ for varlous 1 mog and after removal the observacion of the decay rate of the internal friction peak was continued. The results of this experiment are show 1al $1 \mathrm{~g}$. 8. (18). It 18 seen that the peak decreates in height whlle the nample is in the reactor (pre-irradiation values shown on the ordinate) and that after removal from the reactor the remalning internal friction decays at tha same the regardles of the time spent in the reactox. The toral the at $57^{\circ} \mathrm{C}$ fo show by the solid polnts of Flg. 7. and it can be seen that reactor lrradiation of four hours acclerates prectpitation by a factor of 10 and that turcher irradiation has no effect. Randion ralk conolderations lmply that tho nuber of prectpltation auclel has increased by a factor of 10.

Hull and Hogford (19) performed a binfler experiment withelecton mieroscopy. Siney measured the denstey and size of preclpitato particles in 0.004 wt. \% carbon in iron after both themel and irradtation trentment. After several days of aging at $60^{\circ} \mathrm{C}$, the precipltate particle density was about $3 \times 10^{13} / \mathrm{cm}^{3}$. When quenched irön-cerbon was frxadiated at $60^{\circ} \mathrm{C}$ ia a neutron flux of simflar magnitude to the internel frtetion work, the particle density increased to $2 \times 10^{14} / \mathrm{cm}^{3}$ after 5 hours irradiation. Subsequent irradiations up to 144 hours showed essentlally no change in the nuber of particles alchough their size increased. This independent 
observation of a factor of 10 lacresse la the number of preciptration atces is in cxcelleut ageenent wh the laplications of the internal Exiction atudies. The number of primaty luock-ons from such 1rradintion dises is about $2.3 \times 10^{34} / \mathrm{cm}^{3}$ after 2 houro. If ach forms a nucleation

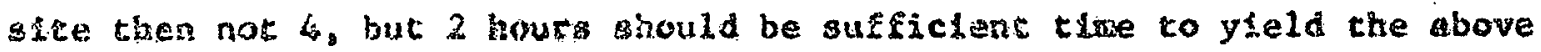
resulig. It not known however, why the incipisnt nuclel created by

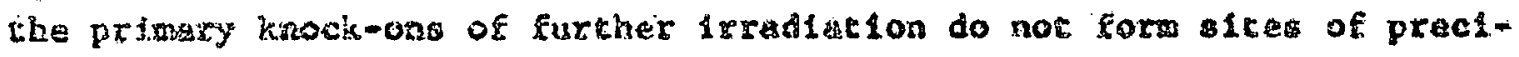
pirate particles. Burtier gtudies of this phenoman need to be made. partlcularly with irraditions os under 4 houss duration.

When the quenched Iron-carbon is arradiated at low cemperature $\left(-100^{\circ} 6\right)$ an entireiy different effect occurs. Heasurements of the rate of dechy of tire internal insecion peak after a 12 day low temperature lio

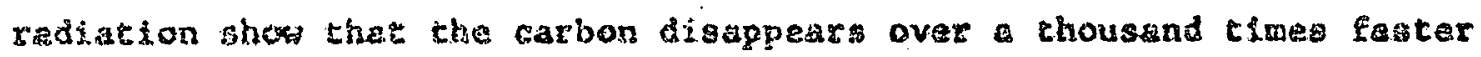

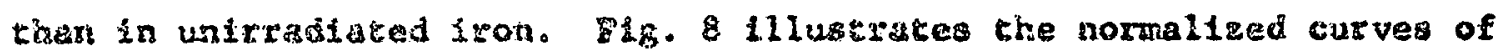
this Aecay at different teaperatures efter a 12 day trradiecton. simflar decsyo for a day irxadition and no trradiation ar also ohown for conpartson. It whould be noted that the decay of the day spectinen does not go to complecton. This faster rate of disagpenrance is 111 turtrated also In $7 \mathrm{~g} .7 \mathrm{in}$ which she $50^{\circ} \mathrm{C}$ curve of $\mathrm{Fig}$. 8 is plotted and ite decay rate at $57^{\circ} \mathrm{C}$ is calcuiated for scorparison. 'When the curves of fig. I are analyzed it is fount thre the disappearance of carbon obeys a second order Toaction rate and fo governed by the figation energy of carbon in iron, $19.8 \mathrm{KcaI} / \mathrm{mol}$. Whe number of jumbs an sverage carbon aton makes before disappearance is calculated to be about 20,000 . This number requires a far greater benstey of nuclei tham could have been created by the 12 day 
irradiation. It 1 belleved, therefore, that the carbon id trapped by point defecta, presumbly the vacancy, and, Edthough it has act prectpitated lnto cluster, its contrlbut on to the knternal friction peali has been renoved. Such vechanism would explain tine, number of jumps, tie order of resction, end the energy that carscols the reaction. It also

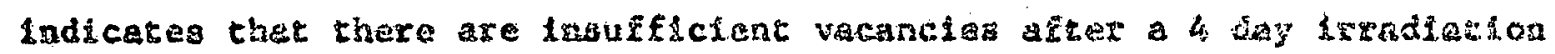
to trap all of the earbon atong in solution In shoge specianens and, theseFore, this decay curve does not shovi the ramoval of all of eta caxton although it obeys second arder kinetses for anegini inftal concencration.

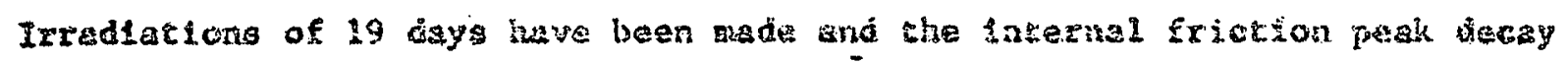

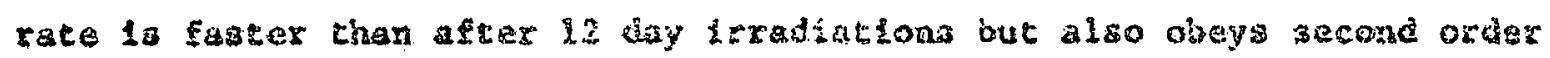

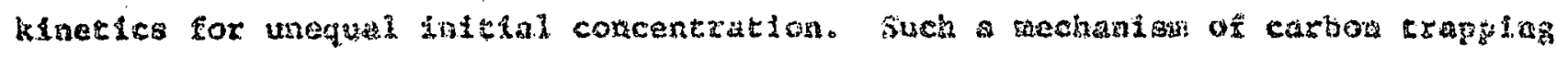

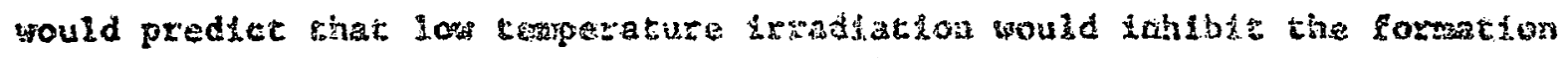
of pracipicaces at $60-60^{\circ} \mathrm{k}$, wet beause there age less nucleation tiges

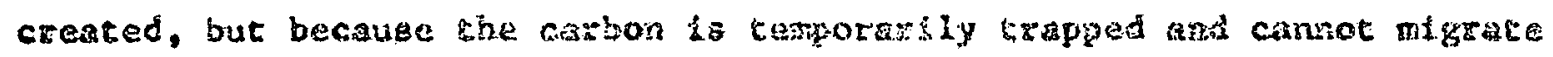

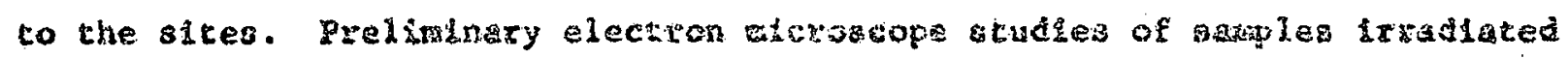

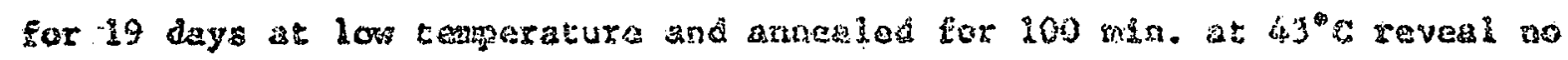

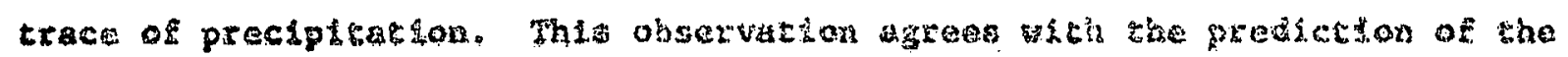
Interpretation of the low cemperature irradation data given gbove.

The bensvior of the carbon fa ixon after low Eemparature lreadistion 1s also being studied sy electical reatstuity and a sonexhat more ze-

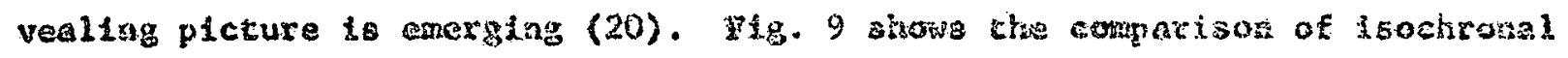
andealing of irradiated and unirradiated quarsed iron-carbon. The un-

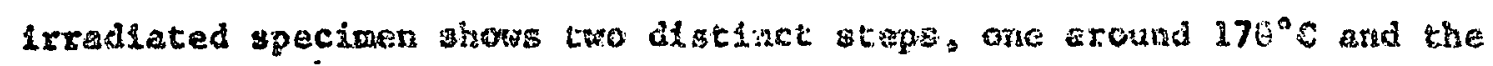
other around $260^{\circ} \mathrm{C}$. The lower tenorature step is the one obstervable by 
Incernal irterdin techntques and is relazed to the prectpliation of catbon from aolution. The high temperture step is associated gith tise coarangement of the precipitate into the feje phase. The trradiated agecimen shüg considerajly wore complexity. A 19 day low texperature irradiation

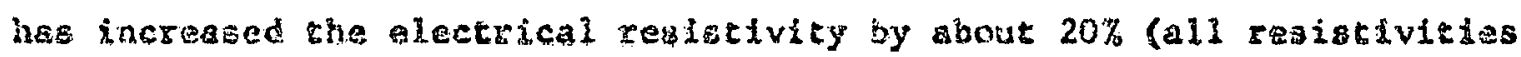
were neasured at ilquid nitrogen remperature). A lan temperature decay

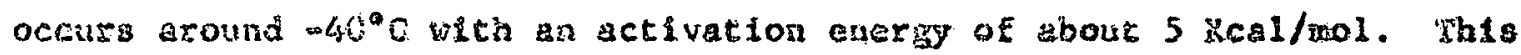
probsuly aziss frow the andeding of one of the polut defects, posalbly sthe hutertitial. A second step accurs around $50^{\circ} \mathrm{C}$ which sorezponda to the faternal friction observation. The activation energy of chis decay

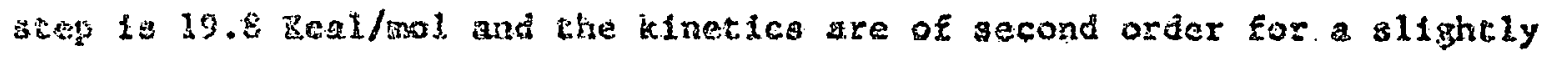

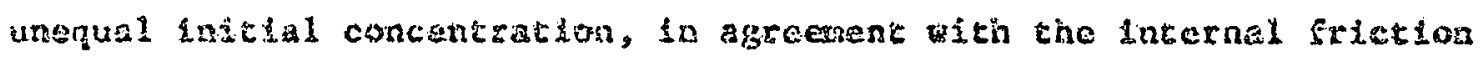
finding. Following this gley is a partal scep wheh has not as get been conglately resolvad, alshough isa activaton energy is around 14 it 2

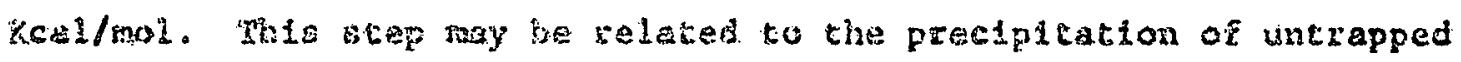
carbon and yould corsegpond to the first atep of the unirsadiated agrple winch also. has wout thats activation onergy. It is hoped that ohorter ir sadation tincs will cause a. fncrease in the anoune of uncrappod carbon and allow this step so be resolved. The hgher tetserature atep is no longer the seme as that of tire unirradtated case, but now appears to conafst of two steps. The first part corresponds in temperature to the high cenperature step in that 1 ts maxtmi rate occurs precisely at $260^{\circ} \mathrm{C}$ and its magnitude is aso near that of the unitratiated step. The decay occurritiz arous 310 appears to be a new otep groduced by the 1radiation and unrelated to the effects observed fin the uafreadiated apecinen. It is 
pertaps the annealing of $x$ esiduel dawage created by nentron Irradlation. It is therefore tentatively assuned that at some reglon the trapped carbon 1a the irradlated sample bolls out of its cxaps and proceeds to

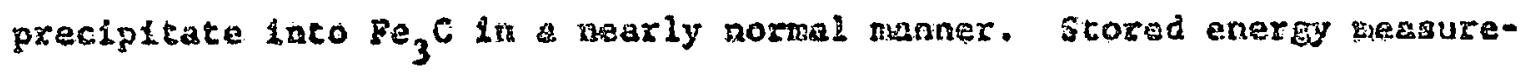
ments currentiy in progress at Brookhaven may reveal a region of energy absorption that could be assigned to the carbon leaving the traps.

The Iron-carbon aystem had been chosen because the nucleation enhansement phenosienon mas expected to be relatively simple, and yet, as was sincun, the problem becane quite complicated. Further compl1cations may be expected during irradition at temperatures in becween the two described here because loth trapping and nucleation shonsld be operative

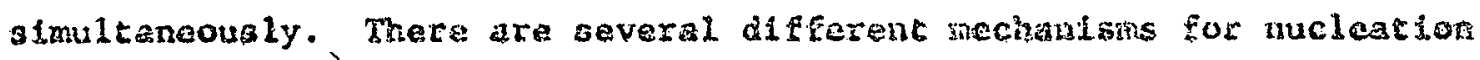
and precipltaklon in alloys, many of whel livolve vacency diffusion. The zork zeported here is, therefore, ony e bagimalng, and studies on many

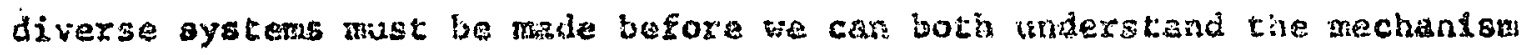
and obtatn quantlative eschates of the enhancerant of nucleation by ix: radiation. 


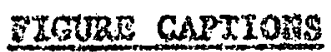

1. Equathrium registrities of chrass meagured at liquid nitrogen tempersture. Axrows are exsmple the to achieve equlliorfun. Oper efrcie at $50^{\circ} \mathrm{C}$ is value obtalned by eleceron trxadiation. (referenes 9 ).

2. Change in electrical resistivity of cubrass with neutron, electron,

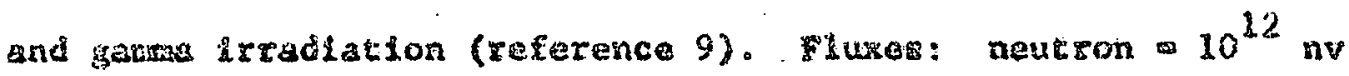

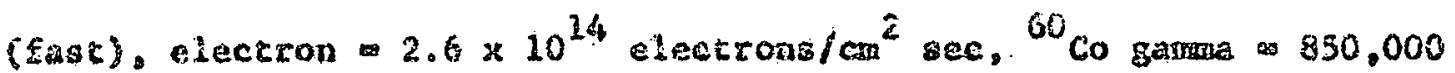
R/hr.

3. Rate of order firg $(1 / 7)$. vi. 1/2 for neutron irradtation of abrass. Solld 1inc - theral rate. Darhed line - theorecical radation on-

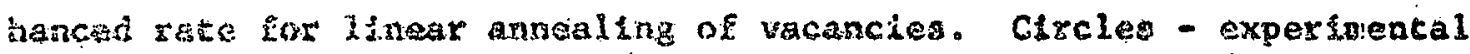

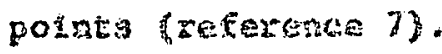

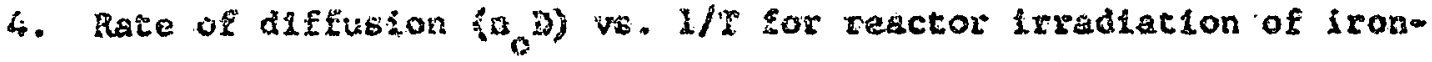
911.10on (referknca 11).

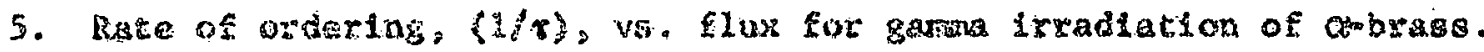

6. Decay of internal frietion peaks at $37^{\circ} \mathrm{C}$ after reactor trradiacion at $57^{\circ} \mathrm{C}$. Pre-15uditation values shown on ordnere. (reference 18 ).

7. Sumber of internal fictecton data. Solid line labelled Thermal is a componte of peak decay at $57^{\circ} \mathrm{C}$ of this expertant coupled whth the curve at $62^{\circ} \mathrm{C}$ of Doxemis. Dashed lige whin data polnts is a curve 
through the solid points of total time at $57^{\circ} \mathrm{C}$. Open points ate frradiation cise only, shown for comparison. Curves on left ars results of 20 tenferature irradiation. (reference 18 ).

8. Hormilized decay curves of internal friction after low temperature reactor izradistion. (reference 18 ).

9. Irochronal decay of resistivity of tron caxbon quenched from $700^{\circ} \mathrm{C}$. (reference 20 ). 


\section{$\operatorname{men} 3$}

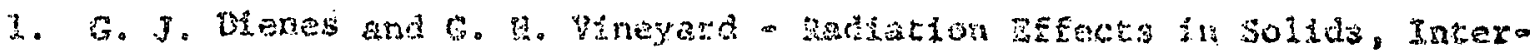

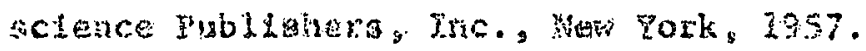

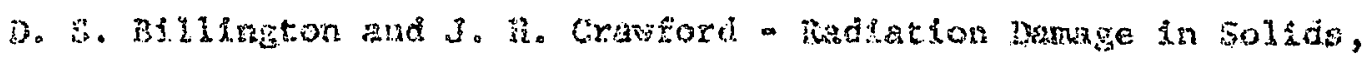

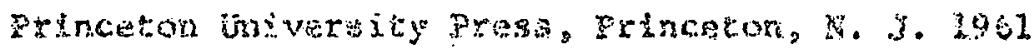

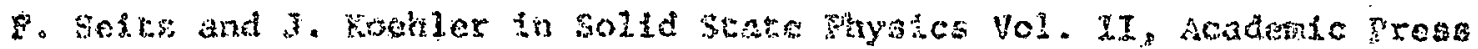

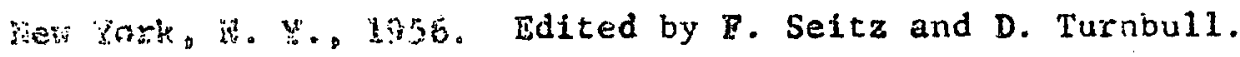

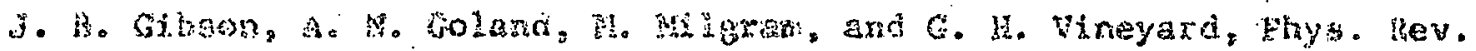
$120.1229(1506)$

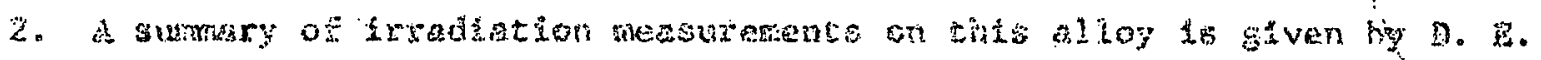

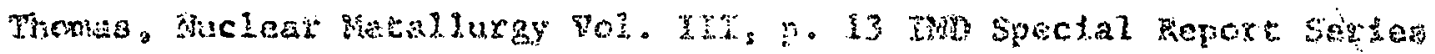

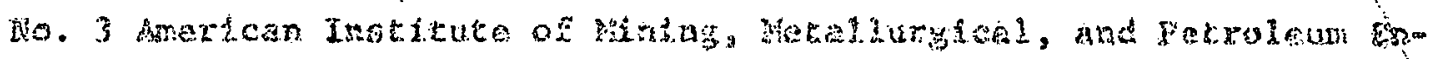
ghneess, Ney Yetz $(3958 \%$.

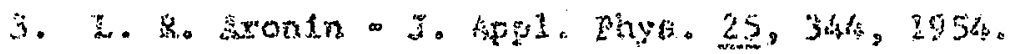

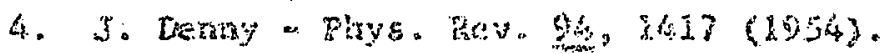

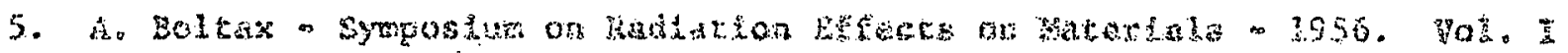

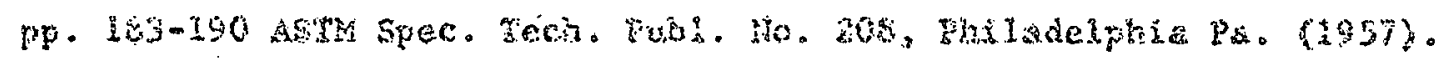

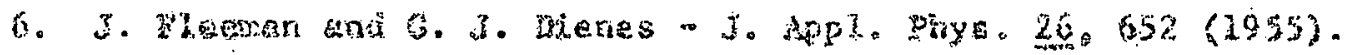

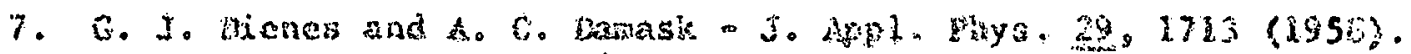

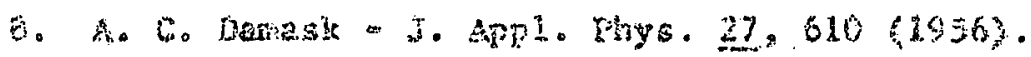

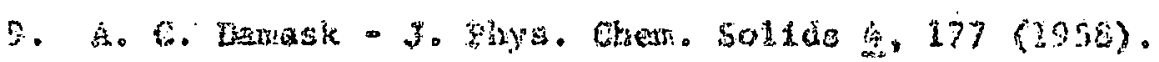

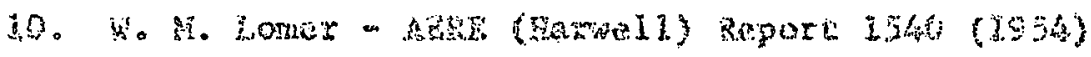

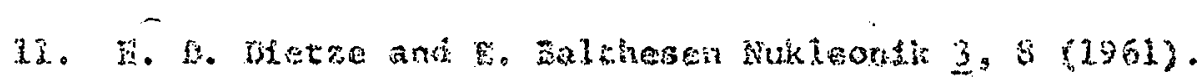




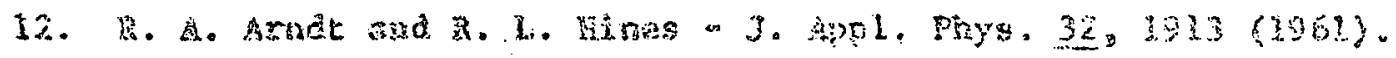

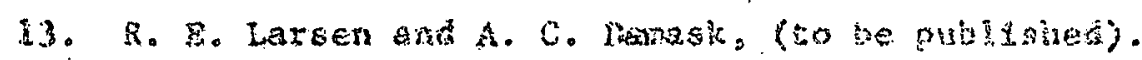

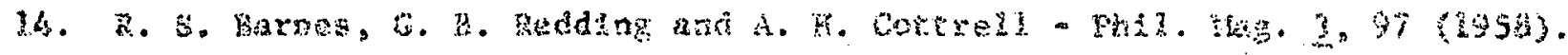

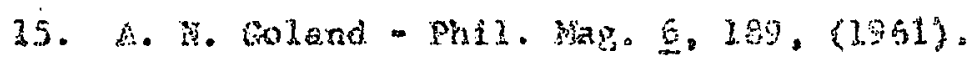

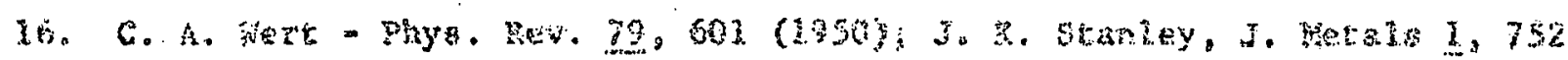

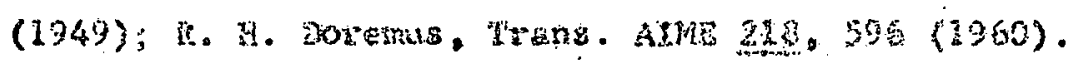

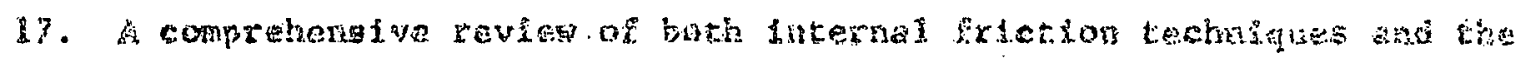

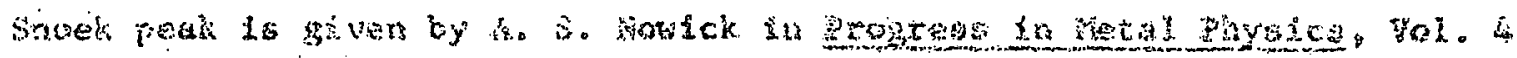
p. 1. Interselence Publebes, Tne, Het rork, 1933.

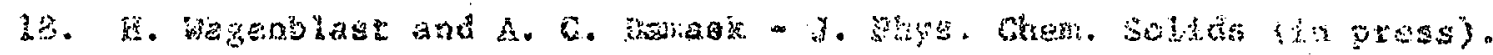

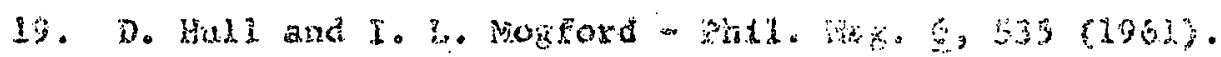

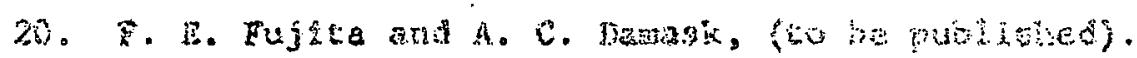


v

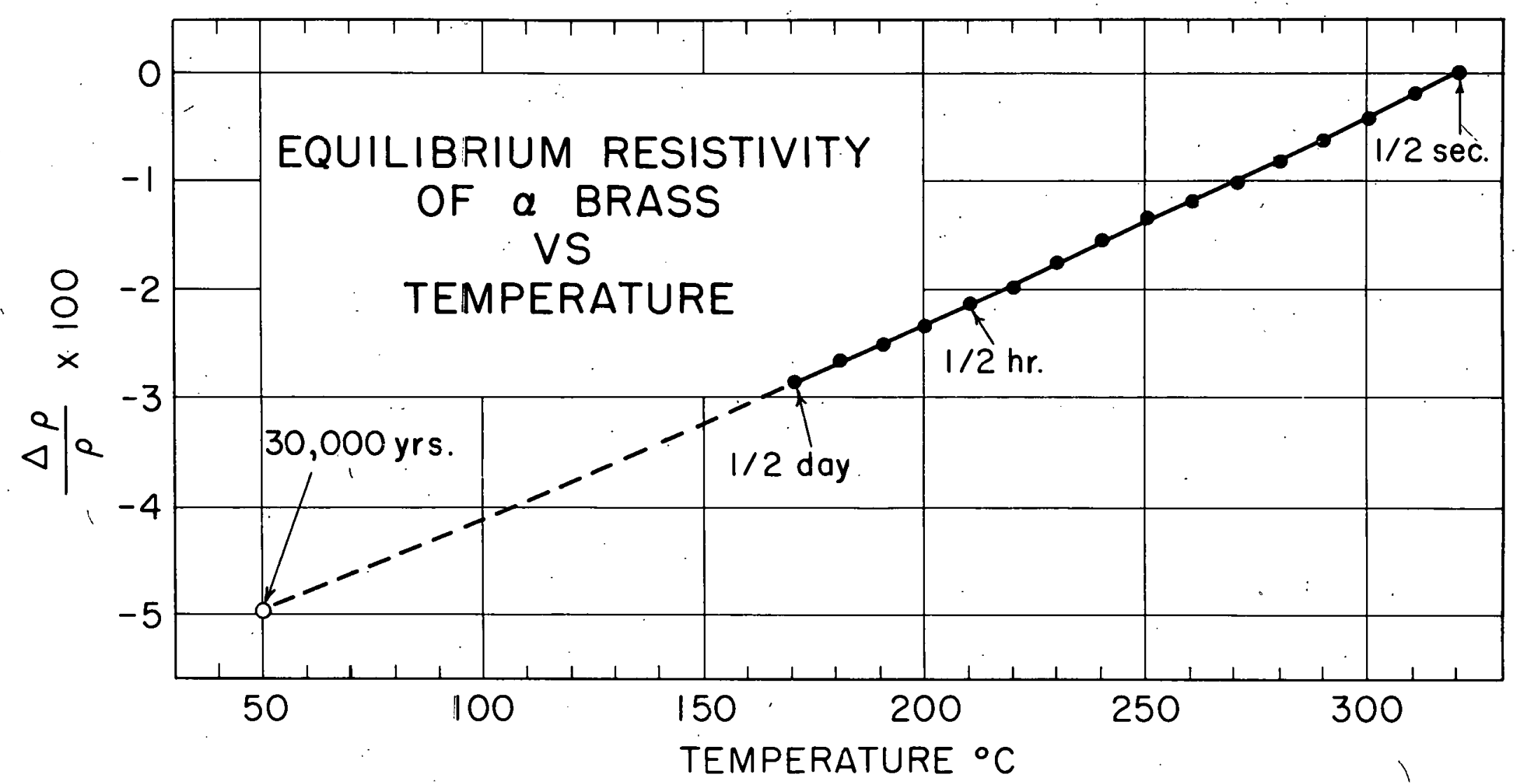

FIG. I 


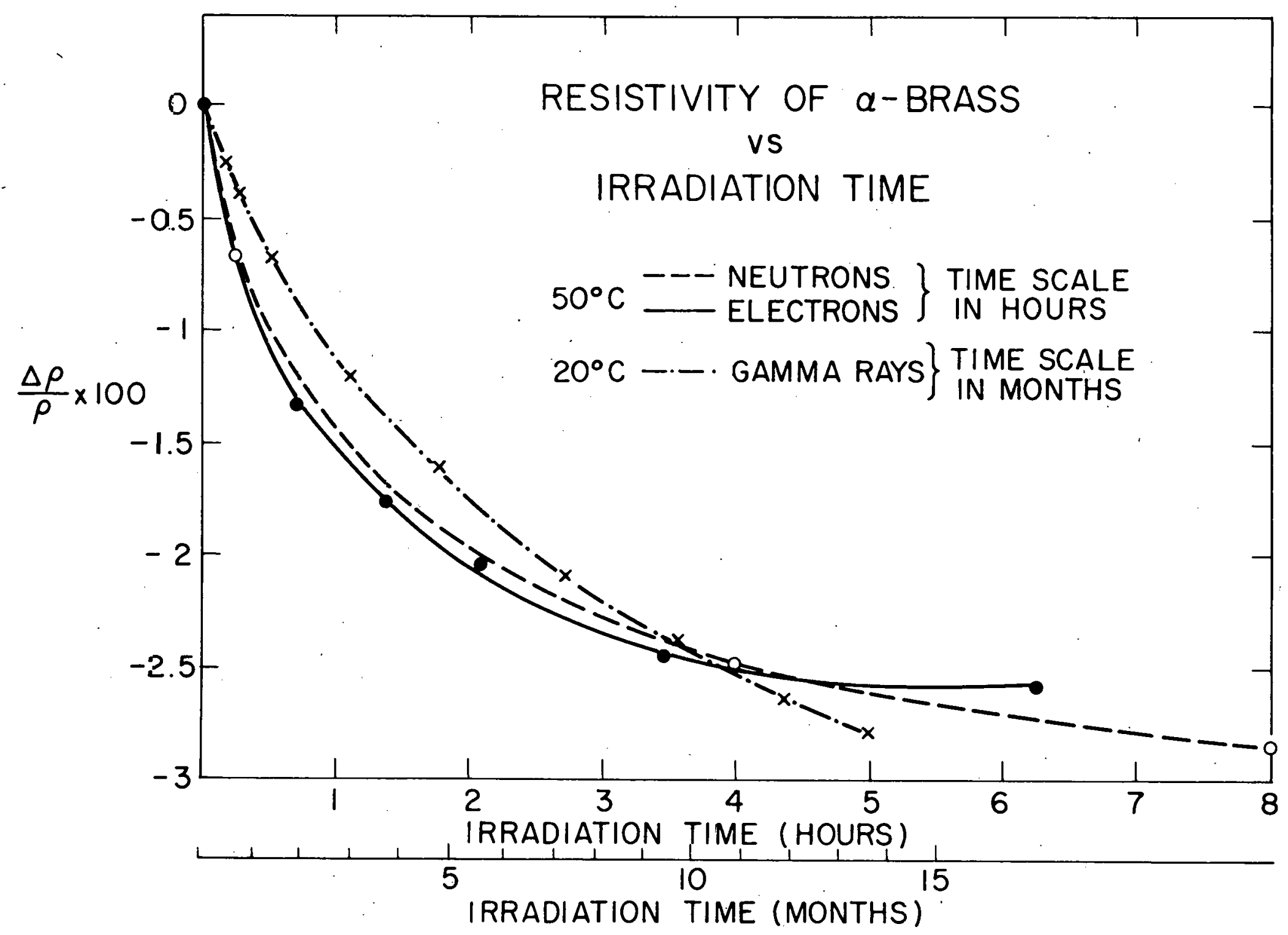

FIG. 2 




FIG. 3

Please refer to: 


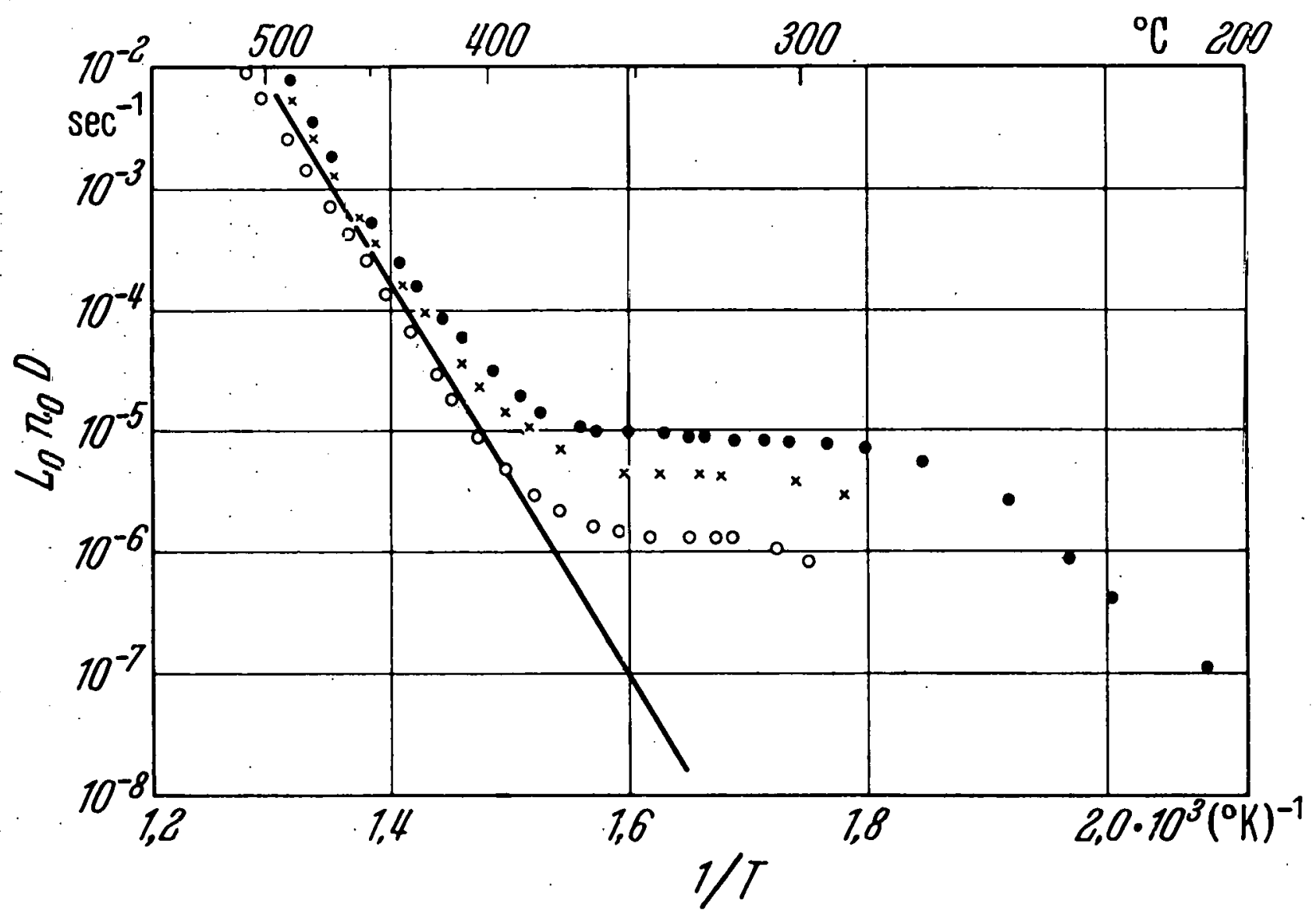

FIG. 4 


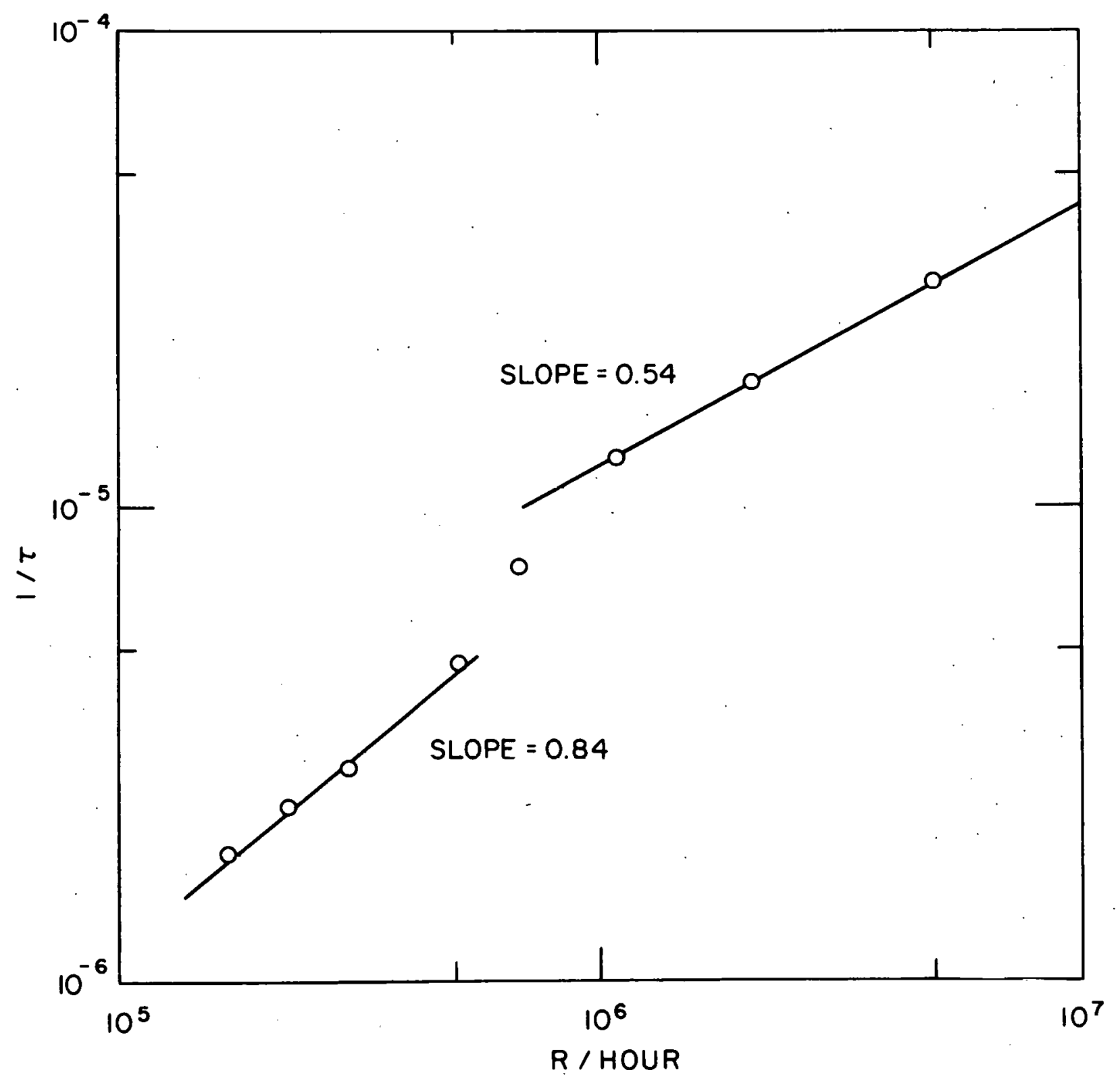

FIG. 5

$\geq 9$

BNL NEP. No $3-241-62$ 


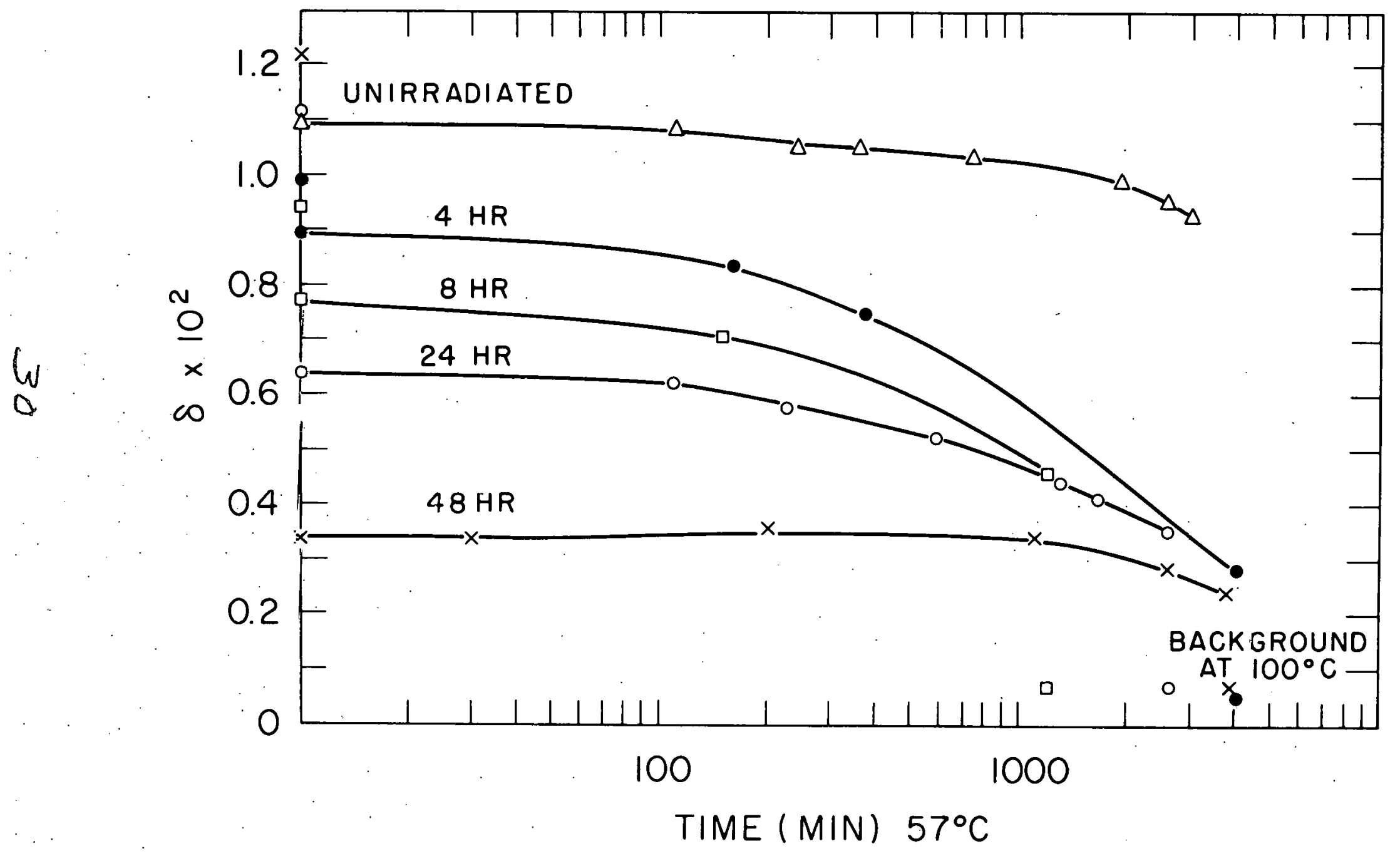

FIG. 6 


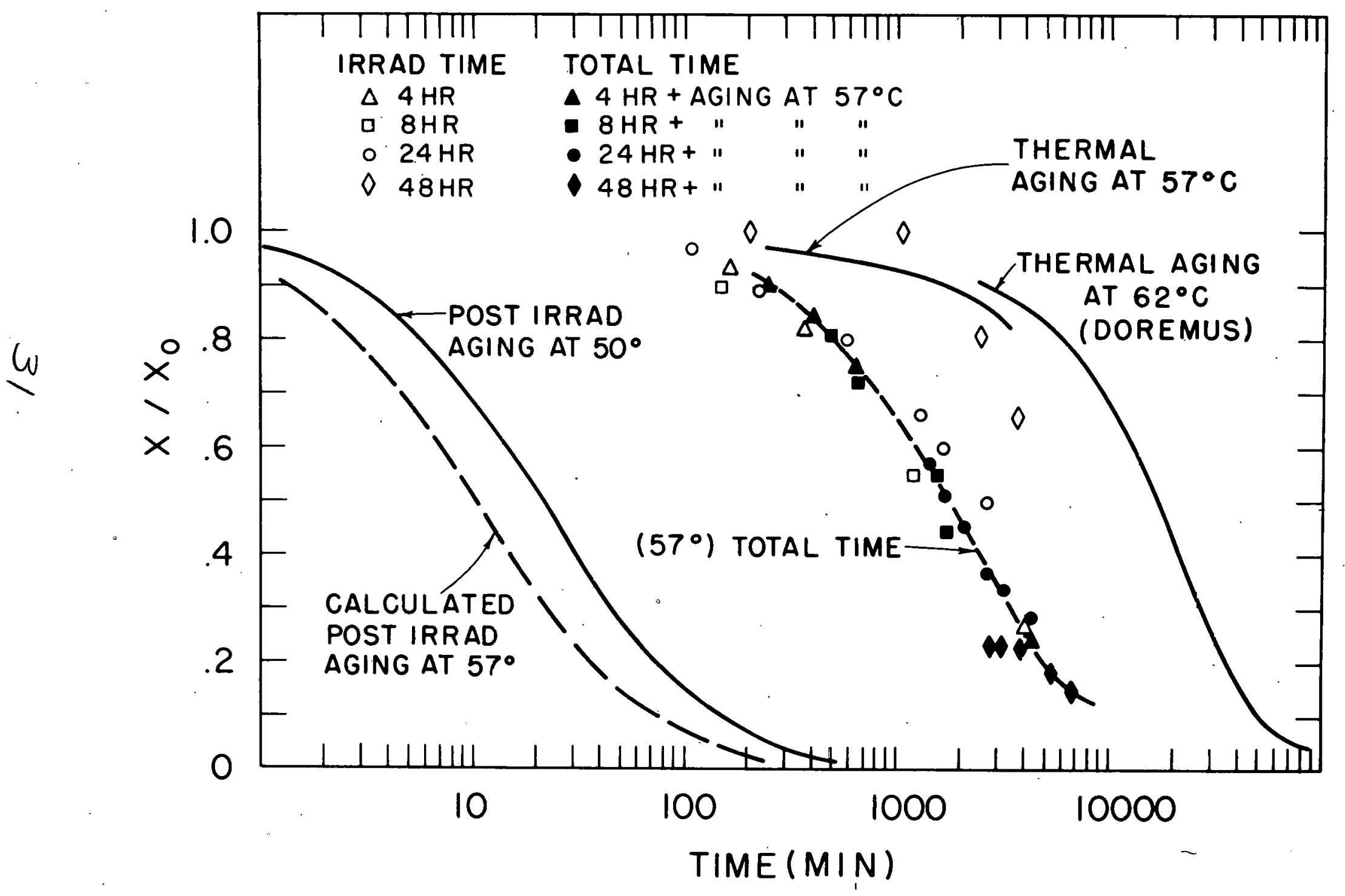

FIG. 7

BNIC NG9.No.3-275-61 


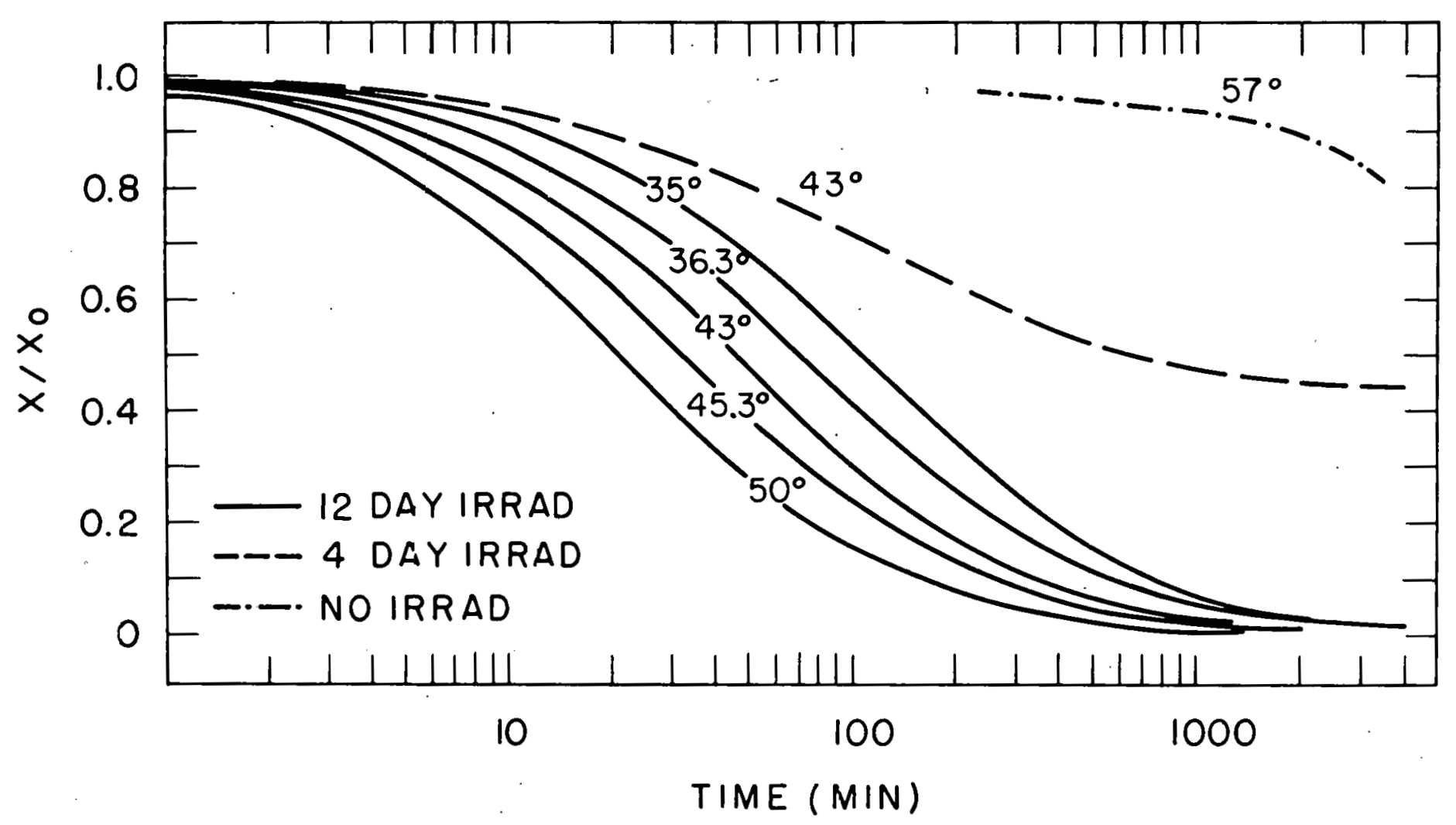

FIG. 8 


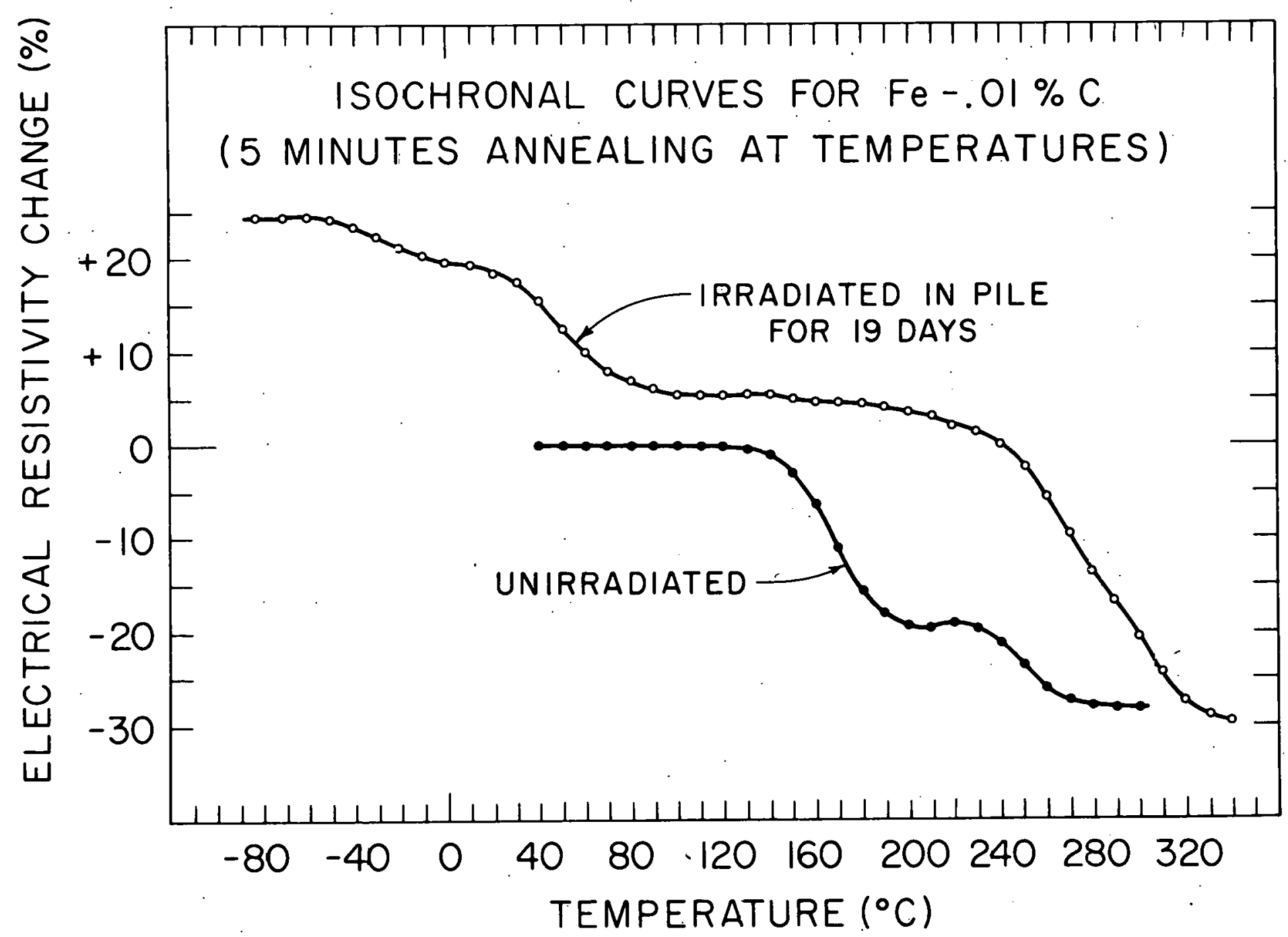

FIG. 9

BNL NET: No: 3-63-62 